\title{
A Dual Wavelength Polymerization and Bioconjugation Strategy for High Throughput Synthesis of Multivalent Ligands
}

\author{
Zihao Li, ${ }^{1 \ddagger}$ Shashank Kosuri, ${ }^{2 \ddagger}$ Henry Foster, ${ }^{1}$ Jarrod Cohen, ${ }^{3}$ Coline Jumeaux,${ }^{4,5}$ Molly M. \\ Stevens, ${ }^{4,5}$ Robert Chapman, ${ }^{* 1}$ Adam J. Gormley*2 \\ ${ }^{1}$ Centre for Advanced Macromolecular Design (CAMD) and the Australian Centre for Nanotechnology \\ (ACN), School of Chemistry, UNSW, Sydney, Australia \\ ${ }^{2}$ Department of Biomedical Engineering, Rutgers, The State University of New Jersey, Piscataway, NJ \\ 08854, USA \\ ${ }^{3}$ New Jersey Center for Biomaterials, Rutgers, The State University of New Jersey, Piscataway, NJ 08854, \\ USA \\ ${ }^{4}$ Department of Materials, Department of Bioengineering, and the Institute for Biomedical Engineering, \\ Imperial College London, London SW7 2AZ, United Kingdom \\ ${ }^{5}$ Division of Medical Biochemistry and Biophysics (MBB), Karolinska Institutet, Stockholm, Sweden
}

\section{SUPPORTING INFORMATION}

\section{Synthetic methods}

Materials and instrumentation: All the raw materials for $\mathrm{cp}$-DIBAC synthesis were purchased either from Sigma, VWR or Fisher Scientific and used as supplied. $\mathrm{m}$-anisidine, m-anisaldehyde, Boc-BetaAlanine- $\mathrm{OH}$, aluminium chloride trace metal basis $\left(\mathrm{AlCl}_{3}\right)$ and triethylamine (TEA) were purchased from Sigma Aldrich, $N$-(3-dimethylaminopropyl)- $N^{\prime}$-ethylcarbodiimide hydrochloride (EDC) from VWR international, hydroxybenzotriazole (HOBT) from Creosalus, and trifluoroacetic acid (TFA), acryloyl chloride and tetrachlorocyclopropene were purchased from Fisher scientific. Solvents DCM, hexane, ethyl acetate and methanol ( $\mathrm{MeOH})$ were purchased from VWR international and used as supplied. All other materials including the catalyst zinc tetraphenyl porphyrin (ZnTPP), the monomers and RAFT agent, and both the $2 \mathrm{kDa}$ and $400 \mathrm{Da}$ azido-PEGs were purchased from Sigma-Aldrich and used as supplied.

${ }^{1} \mathrm{H}$ NMR spectra for monomer synthesis were obtained on a Varian VNMRS $500 \mathrm{MHz}$ spectrometer and processed using Mestrenova 11.0.4. Molecular weights for linear polymers were determined using Agilent 1200 series GPC with differential refractive index (RI) detector and UV detector (265 $\mathrm{nm}$ ) at $2 \mathrm{mg} / \mathrm{mL}$ concentration in DMF with $50 \mathrm{mM} \mathrm{LiBr}$ as the eluent. ${ }^{1} \mathrm{H}$ NMR spectra for star RAFT agent synthesis and star polymers were obtained with Bruker $300 \mathrm{MHz}$ or $400 \mathrm{MHz}$ spectrometers and processed using Topspin 3.6. The molecular weight distributions and molecular weights of star polymers were analysed via GPC with a Shimadzu modular system consisting three Phenomexex 5.0 $\mu \mathrm{m}$ bead-size columns $\left(10^{5}, 10^{4}\right.$ and $\left.10^{3} \AA\right)$ and RID-10A refractive index detector. DMF containing $0.1 \% \mathrm{LiBr}$ and $0.04 \%$ 4-methoxyphenol was used as the mobile phase (flow rate $=1 \mathrm{~mL} \cdot \mathrm{min}^{-1}$ ). The instrument was calibrated with commercially available linear PMMA standards (Polymer Laboratories).

LC-MS was run on a Shimadzu LCMS2020 using an analytical C18 column, and a gradient of $10-100 \%$ $(\mathrm{v} / \mathrm{v}) \mathrm{MeCN}$ in water over $26 \mathrm{~min} .0 .1 \%(\mathrm{v} / \mathrm{v})$ formic acid was added to each eluent. Samples were prepared at $\sim 0.1 \mathrm{mg} / \mathrm{ml}$ in $1: 1 \mathrm{MeCN} /$ water $(\mathrm{v} / \mathrm{v})$ after removal of the DMSO in vacuo. $10 \mu \mathrm{L}$ injections were used in each run, and the mass spectra (in positive and negative mode, $\mathrm{m} / \mathrm{z}=50$ 2000) and UV spectra (190-800 nm) were recorded as a function of time. 
cp-DIBAC monomer synthesis procedure:

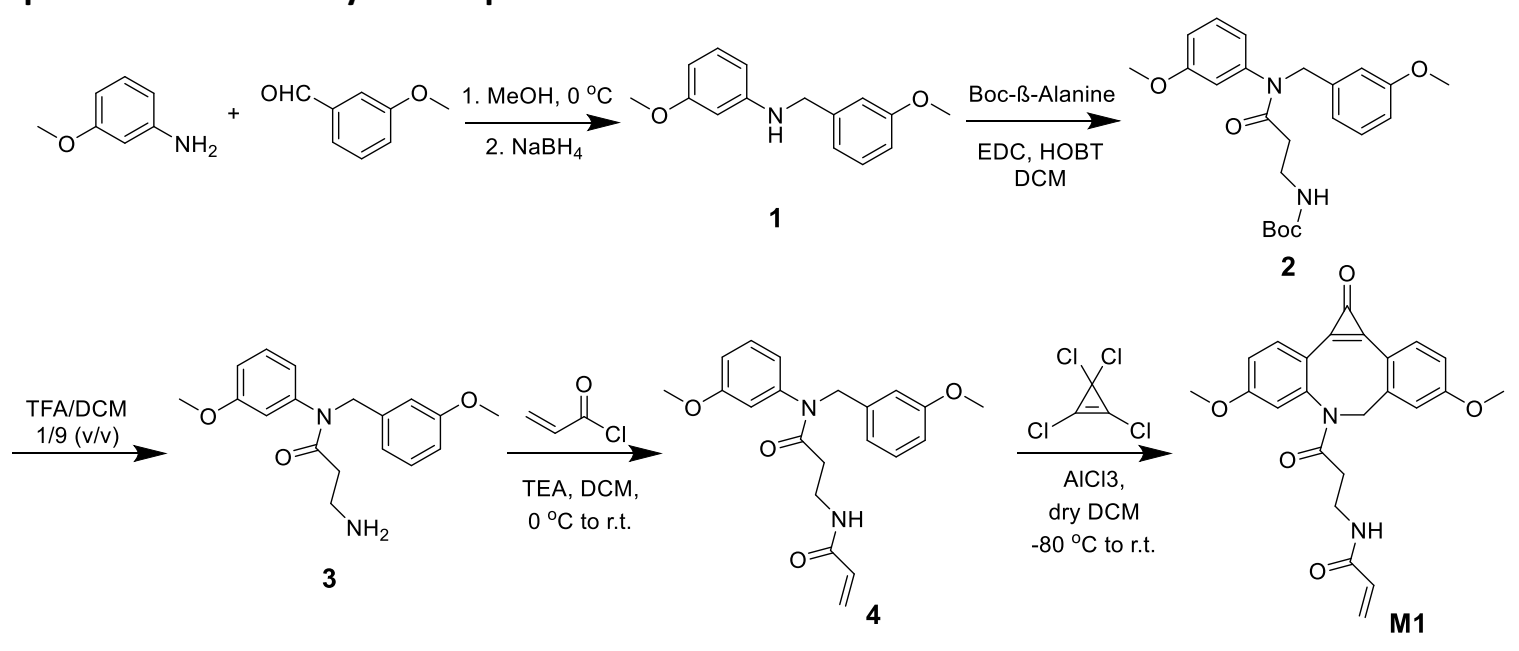

Scheme S1: Synthetic route of cp-DIBAC monomer M1

Synthesis of 1: m-Anisidine ( $5 \mathrm{~g}, 40.6 \mathrm{mmol}, 1.1 \mathrm{eq}), \mathrm{m}$-anisaldehyde $(5.02 \mathrm{~g}, 36.9 \mathrm{mmol}, 1 \mathrm{eq}), 100$ $\mathrm{mL}$ methanol and a magnetic stir bar were added to a $250 \mathrm{~mL}$ round bottom flask (RBF) and allowed to mix for $2 \mathrm{~h}$ on an ice bath $\left(0^{\circ} \mathrm{C}\right)$. Sodium borohydride $(4.2 \mathrm{~g}, 220,3 \mathrm{eq})$ was added slowly for over a period of $1 \mathrm{~h}$ and the mixture was allowed to stir for an additional $2 \mathrm{~h}$ on ice prior to work up. 150 $\mathrm{mL}$ of deionized water $\left(\mathrm{DI} \mathrm{H}_{2} \mathrm{O}\right)$ was added slowly to quench the reaction causing a solid to form and precipitate out. The mixture was then extracted using ethyl acetate $(3 \times 100 \mathrm{~mL})$ to separate the organic phase. Organic phases were then combined and washed with $0.5 \mathrm{M} \mathrm{HCl}(2 \times 100 \mathrm{~mL})$ to remove unreacted aniline followed by $2 \mathrm{M} \mathrm{NaOH}(2 \times 100 \mathrm{~mL})$, DI $\mathrm{H}_{2} \mathrm{O}(2 \times 50 \mathrm{~mL})$, brine $(1 \times 100 \mathrm{~mL})$ and finally dried over $\mathrm{Na}_{2} \mathrm{SO}_{4}$ for 10 minutes, filtered, and concentrated in vacuo to obtain a brown liquid. The liquid was air dried overnight to obtain the pure compound $\mathbf{1}$ (7.9 g, 80\% yield). ${ }^{1} \mathrm{H}$ NMR (500 MHz, d6-DMSO) $\delta 7.28-7.16(\mathrm{~m}, 1 \mathrm{H}), 6.91$ (tdd, $J=7.5,6.7,5.6,2.8 \mathrm{~Hz}, 3 \mathrm{H}), 6.80-6.73(\mathrm{~m}$, $1 \mathrm{H}), 6.24-6.13(\mathrm{~m}, 2 \mathrm{H}), 6.13-6.04(\mathrm{~m}, 2 \mathrm{H}), 4.20(\mathrm{dd}, J=6.2,2.1 \mathrm{~Hz}, 2 \mathrm{H}), 3.70(\mathrm{q}, J=2.7,2.2 \mathrm{~Hz}, 3 \mathrm{H})$, $3.61(q, J=2.0 \mathrm{~Hz}, 3 \mathrm{H})$.

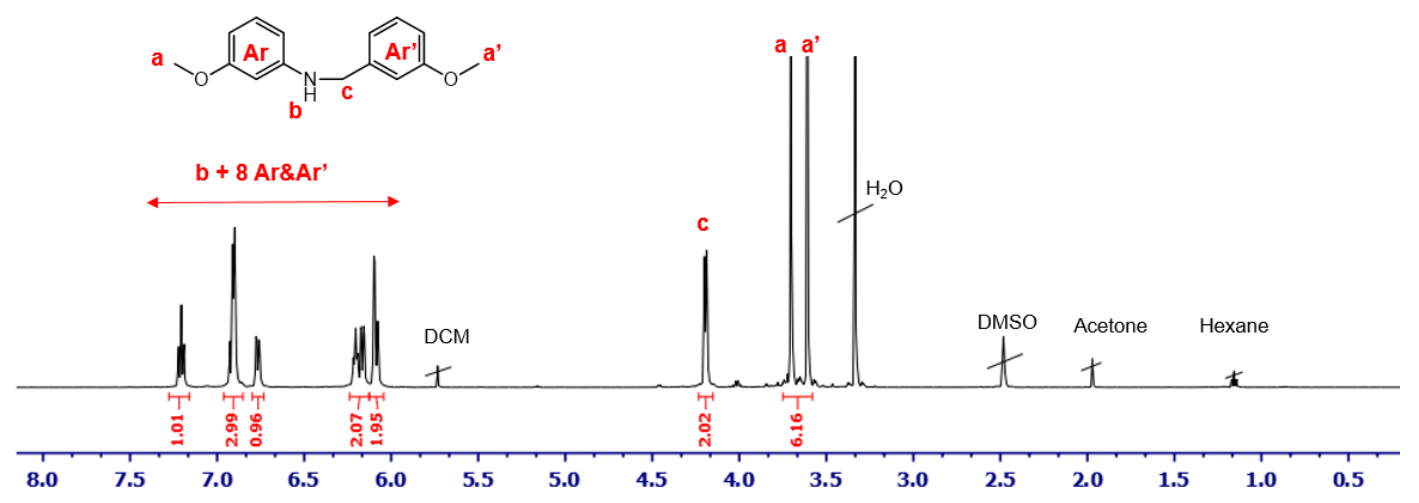

Figure S1: ${ }^{1} \mathrm{H}$ NMR (500 MHz d6-DMSO) of 1

Synthesis of 2: Product 1 ( $4.5 \mathrm{~g}, 18.5 \mathrm{mmol}, 1 \mathrm{eq})$ was mixed with Boc-Beta-alanine-OH (4.19 g, 22.14 $\mathrm{mmol}, 1.2 \mathrm{eq})$, EDC ( $4.97 \mathrm{~g}, 25.89 \mathrm{mmol}, 1.4 \mathrm{eq})$, and HOBT (0.34 g, $2.2 \mathrm{mmol}, 0.12 \mathrm{eq})$ in $100 \mathrm{~mL}$ $\mathrm{DCM}$ with a stir bar and allowed to mix for $30 \mathrm{~h}$. The organic mixture was then washed with DI water $(2 \times 100 \mathrm{~mL}), 2 \mathrm{M} \mathrm{NaOH}(1 \times 100 \mathrm{~mL})$, DI water $(1 \times 100 \mathrm{~mL})$ and finally with brine $(1 \times 100 \mathrm{~mL})$ before being dried over $\mathrm{Na}_{2} \mathrm{SO}_{4}$ and concentrated in vacuo. The crude product was purified using column 
chromatography over silica (30:70 ethyl acetate: hexane) to yield the product as a brownish-red liquid 2 (3.44 g, 45\%). ${ }^{1} \mathrm{H}$ NMR (500 MHz, d6-DMSO) $\delta 7.22$ (dt, $\left.J=35.0,7.6 \mathrm{~Hz}, 2 \mathrm{H}\right), 6.88$ (d, $J=8.2$ $\mathrm{Hz}, 1 \mathrm{H}), 6.82-6.65(\mathrm{~m}, 6 \mathrm{H}), 4.82(\mathrm{~s}, 2 \mathrm{H}), 4.03(\mathrm{t}, J=7.2 \mathrm{~Hz}, 1 \mathrm{H}), 3.70(\mathrm{~s}, 6 \mathrm{H}), 3.41(\mathrm{~s}, 1 \mathrm{H}), 2.28(\mathrm{~s}, 2 \mathrm{H})$, $1.34(\mathrm{~s}, 9 \mathrm{H})$.

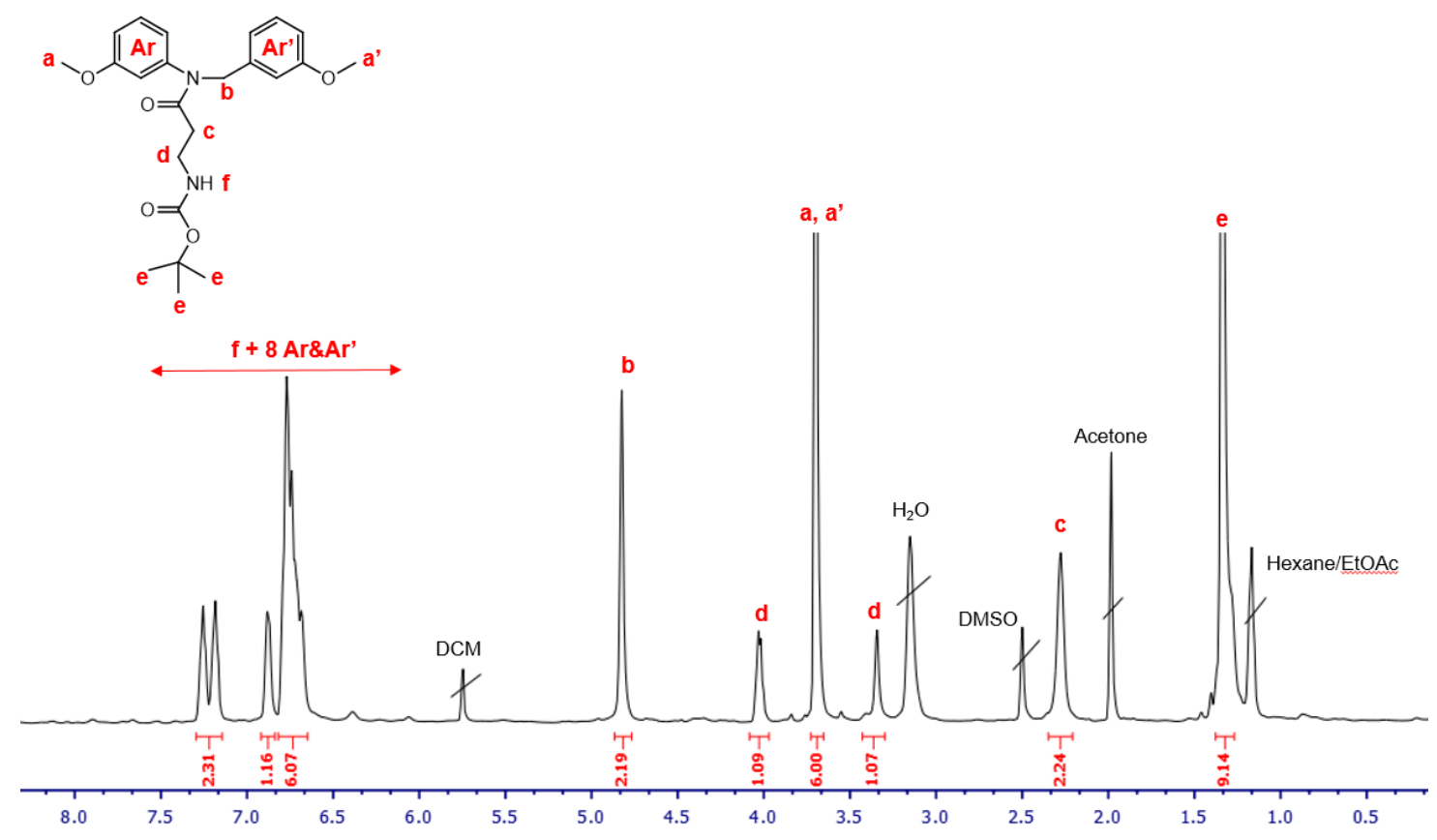

Figure S2: ${ }^{1} \mathrm{H}$ NMR (500 MHz d6-DMSO) of 2

Synthesis of 3: Product 2 ( $3.44 \mathrm{~g}, 8.3 \mathrm{mmol})$ was dissolved in $50 \mathrm{~mL}$ of TFA and DCM (1:9, v:v) and allowed to stir for $4 \mathrm{~h}$ at room temperature for boc deprotection. The resulting solution was washed with $0.6 \mathrm{M} \mathrm{NaHCO}_{3}(2 \times 50 \mathrm{~mL})$, DI water $(1 \times 50 \mathrm{~mL})$ and finally with brine $(1 \times 50 \mathrm{~mL})$ before being dried over $\mathrm{Na}_{2} \mathrm{SO}_{4}$ and concentrated in vacuo to yield the pure product as a dark pink liquid $\mathbf{3}(1.82 \mathrm{~g}$, 70\%). Note: Sodium bicarbonate wash is necessary to completely remove any TFA present even though this results in a decreased yield of product 3 because it will react with TEA in step 4 thereby affecting the stoichiometry. ${ }^{1} \mathrm{H} \mathrm{NMR}(500 \mathrm{MHz}, d 6$-DMSO) $\delta 7.26(\mathrm{t}, J=8.1 \mathrm{~Hz}, 1 \mathrm{H}), 7.18(\mathrm{t}, J=7.9 \mathrm{~Hz}$, $1 \mathrm{H}), 6.89-6.84(\mathrm{~m}, 1 \mathrm{H}), 6.79-6.68(\mathrm{~m}, 5 \mathrm{H}), 4.80(\mathrm{~s}, 2 \mathrm{H}), 3.68(\mathrm{~d}, J=5.6 \mathrm{~Hz}, 6 \mathrm{H}), 2.73(\mathrm{t}, J=6.6 \mathrm{~Hz}$, $2 \mathrm{H}), 2.21(\mathrm{~s}, 2 \mathrm{H})$.

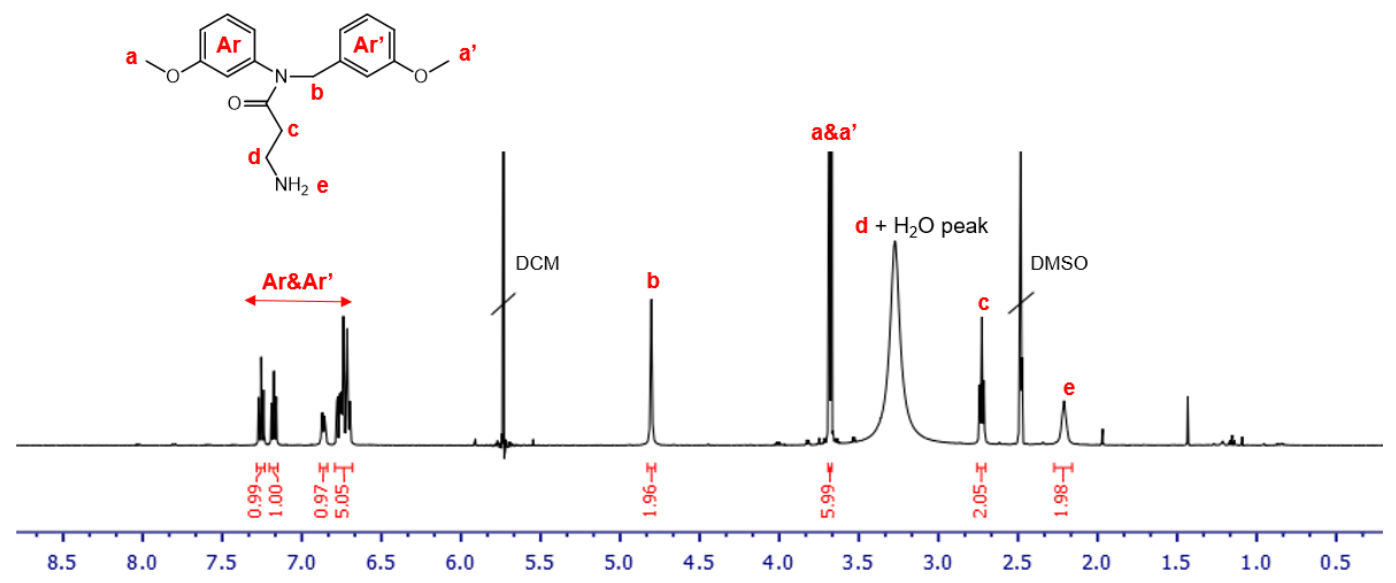

Figure S3: ${ }^{1} \mathrm{H}$ NMR (500 MHz d6-DMSO) of 3 
Synthesis of 4: Product 3 (1.82 g, $5.79 \mathrm{mmol}, 1 \mathrm{eq})$ was mixed with $50 \mathrm{~mL}$ of DCM in a $100 \mathrm{~mL} R B F$ equipped with a magnetic stir bar and rubber septa and was placed on an ice bath at $0{ }^{\circ} \mathrm{C}$. TEA (1.61 $\mathrm{mL}, 11.58 \mathrm{mmol}, 2 \mathrm{eq}$ ) was added dropwise to the mixture using a syringe and was allowed to stir for half an hour at $0{ }^{\circ} \mathrm{C}$. Acryloyl chloride $(470 \mu \mathrm{L}, 5.79 \mathrm{mmol}, 1 \mathrm{eq})$ was then added dropwise carefully and the mixture was allowed to stir on the ice bath for an additional $2 \mathrm{~h}$, cooled down to room temperature and continued stirring for additional $16 \mathrm{hrs}$ before quenching it with $10 \mathrm{~mL}$ of methanol. Resulting solution was then washed with $0.1 \mathrm{M} \mathrm{HCl}(1 \times 50 \mathrm{~mL})$, DI water $(2 \times 50 \mathrm{~mL})$ and finally with brine (1x $50 \mathrm{~mL}$ ) before being dried over $\mathrm{Na}_{2} \mathrm{SO}_{4}$ and concentrated in vacuo. The crude was then purified with column chromatography over silica using $5 \% \mathrm{MeOH}$ in $\mathrm{DCM}(\mathrm{v} / \mathrm{v})$ to obtain the product 4 as a light pink liquid (1.109 g, 52\%). ${ }^{1} \mathrm{H}$ NMR (500 MHz, d6-DMSO) $\delta 8.08$ (s, $\left.1 \mathrm{H}\right), 7.21$ (dtd, $J=34.6$, 8.0, $1.5 \mathrm{~Hz}, 2 \mathrm{H}), 6.90-6.83(\mathrm{~m}, 1 \mathrm{H}), 6.79-6.66(\mathrm{~m}, 5 \mathrm{H}), 6.15$ (ddd, $J=17.1,10.2,1.5 \mathrm{~Hz}, 1 \mathrm{H}), 6.00$ $(\mathrm{dt}, J=17.2,2.0 \mathrm{~Hz}, 1 \mathrm{H}), 5.51(\mathrm{dt}, J=10.1,1.9 \mathrm{~Hz}, 1 \mathrm{H}), 4.81(\mathrm{~s}, 2 \mathrm{H}), 3.68(\mathrm{~d}, J=1.5 \mathrm{~Hz}, 6 \mathrm{H}), 2.30(\mathrm{t}, J=$ $7.0 \mathrm{~Hz}, 2 \mathrm{H})$.

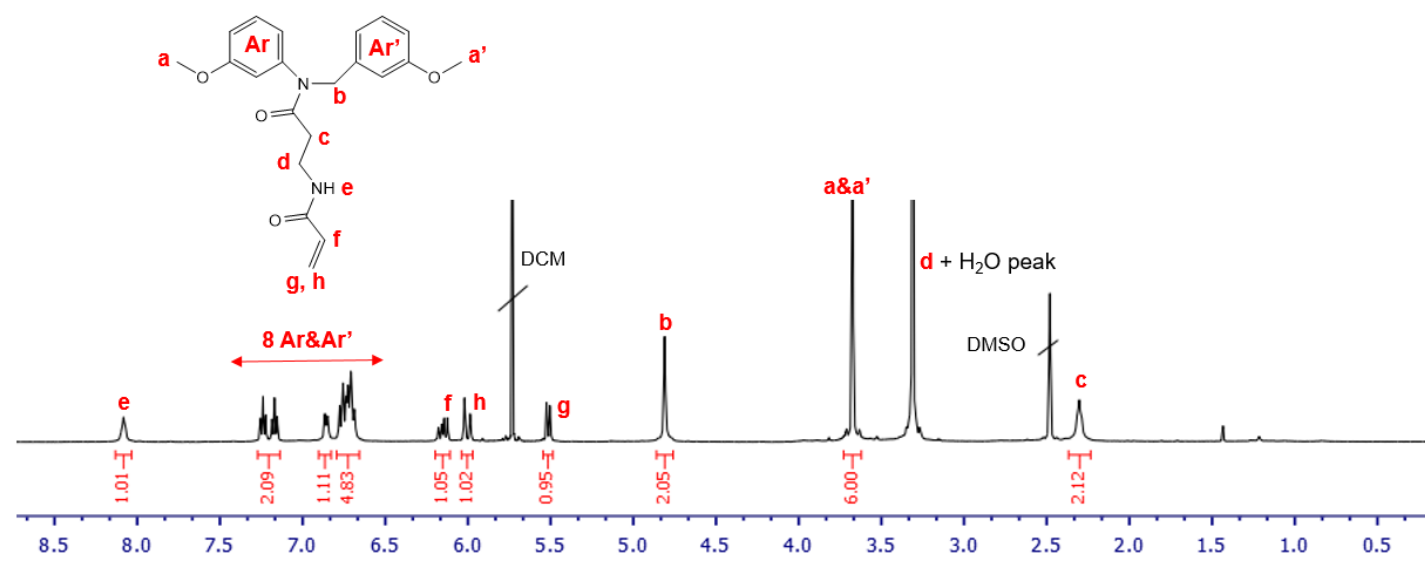

Figure S4: ${ }^{1} \mathrm{H}$ NMR (500 MHz d6-DMSO) of 4

Synthesis of M1: $50 \mathrm{~mL}$ of anhydrous DCM was added to a $100 \mathrm{~mL}$ flame dried two neck round bottom flask with a stir bar (one port with $\mathrm{N}_{2}$ inlet and the other closed with a septum) and was cooled in an acetone-dry ice bath to $-80{ }^{\circ} \mathrm{C}$. The $\mathrm{N}_{2}$ exhaust was removed after 10 min and $\mathrm{AlCl}_{3}$ $(1.60 \mathrm{~g}, 12.04 \mathrm{mmol}, 4 \mathrm{eq})$ was added very quickly and the inlet was closed once again. Tetrachlorocyclopropene ( $591 \mu \mathrm{L}, 4.82 \mathrm{mmol}, 1.6 \mathrm{eq})$ was added dropwise to the mixture through the septum via syringe-needle system and was allowed to stir for an hour at $-80{ }^{\circ} \mathrm{C}$. Product $4(1.109$ $\mathrm{g}, 3.01 \mathrm{mmol}, 1 \mathrm{eq}$ ) was dissolved in $5 \mathrm{~mL}$ of anhydrous DCM and was added dropwise very slowly for over a period of one hour. After the addition of 4, the reaction mixture was allowed to stir at -80 ${ }^{\circ} \mathrm{C}$ for another $2.5 \mathrm{~h}$ and later at room temperature overnight (16 h). The reaction was quenched by adding $10 \% \mathrm{HCl}(10 \mathrm{~mL})$ and was allowed to stir for another $5 \mathrm{~min}$. The organic mixture was extracted with $50 \mathrm{~mL}$ of hexane and then washed with DI water $(2 \times 100 \mathrm{~mL})$ and brine $(1 \times 50 \mathrm{~mL})$ before being dried over $\mathrm{Na}_{2} \mathrm{SO}_{4}$ and concentrated in vacuo. The crude was purified by column chromatography over silica (10\% methanol in DCM v/v) to yield $\mathbf{M 1}$ as a pale white solid (138 $\mathrm{mg}$, 11\%). ${ }^{1} \mathrm{H}$ NMR (500 MHz, d6-DMSO) $\delta 7.89$ (d, $\left.J=5.6 \mathrm{~Hz}, 2 \mathrm{H}\right), 7.74(\mathrm{~d}, J=7.8 \mathrm{~Hz}, 1 \mathrm{H}), 7.28(\mathrm{~d}, J=11.1$ $\mathrm{Hz}, 2 \mathrm{H}), 7.17(\mathrm{~d}, J=8.5 \mathrm{~Hz}, 1 \mathrm{H}), 7.07(\mathrm{~d}, J=8.1 \mathrm{~Hz}, 1 \mathrm{H}), 6.06-5.89(\mathrm{~m}, 2 \mathrm{H}), 5.48(\mathrm{~d}, J=9.6 \mathrm{~Hz}, 1 \mathrm{H})$, $5.04(\mathrm{~d}, J=14.6 \mathrm{~Hz}, 1 \mathrm{H}), 4.23(\mathrm{~d}, J=14.8 \mathrm{~Hz}, 1 \mathrm{H}), 3.89(\mathrm{~s}, 6 \mathrm{H}), 3.16(\mathrm{~s}, 1 \mathrm{H}), 3.01(\mathrm{~s}, 1 \mathrm{H}), 2.04-1.90$ (m, 1H). 


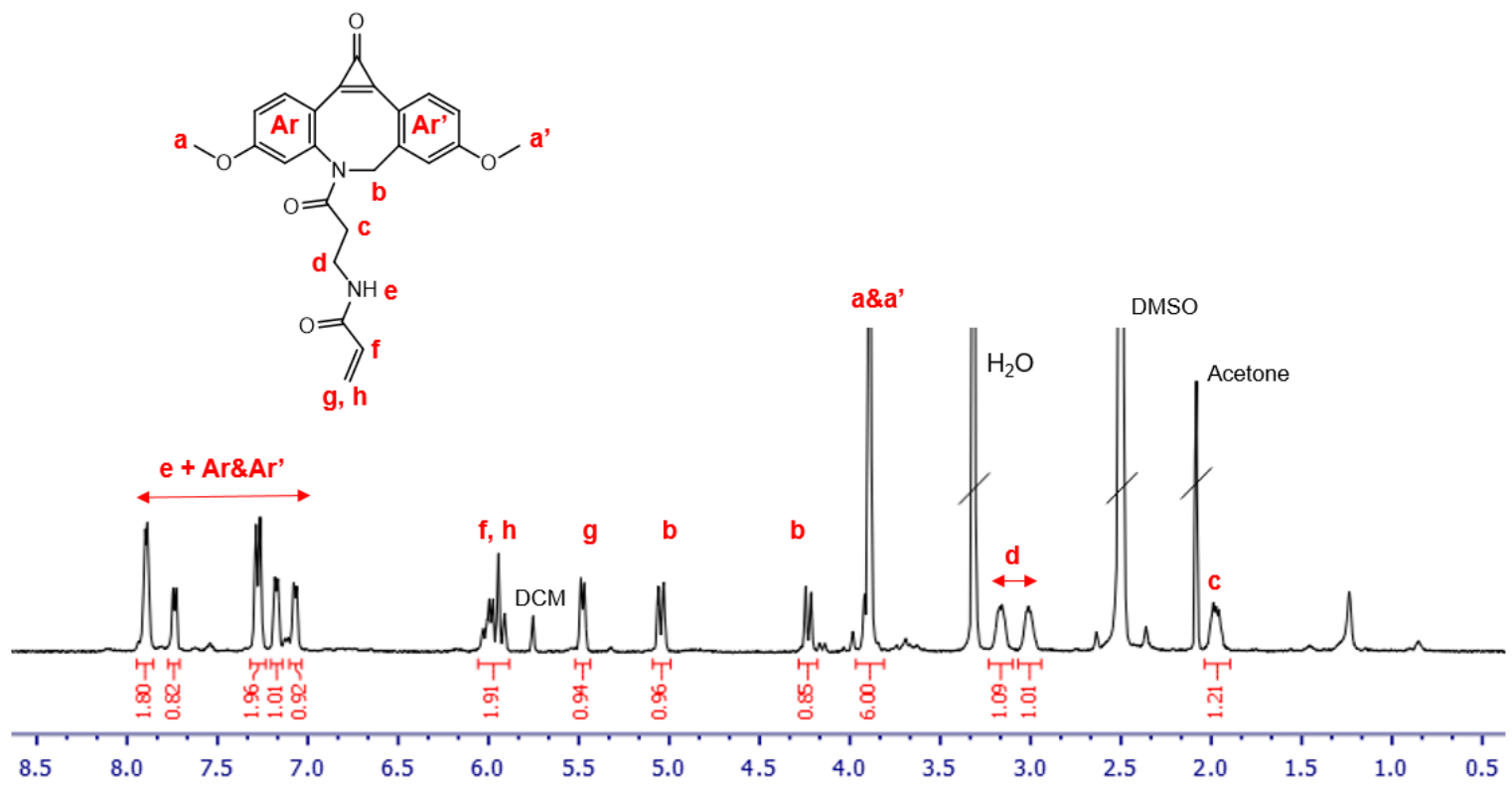

Figure S5: ${ }^{1} \mathrm{H}$ NMR (500 MHz d6-DMSO) of M1

Materials and instrumentation for star RAFT agent and polymer synthesis: ${ }^{1} \mathrm{H}$ NMR spectra were obtained on a Bruker $300 \mathrm{MHz}$ or $400 \mathrm{MHz}$ spectrometer and processed using Topspin 3.6.

The star polymers were characterised with a Shimadzu modular system consisting of DGU-12A degasser, LC-10AT pump, SIL-10AD auto-injector, CTO-10A column oven $\left(50{ }^{\circ} \mathrm{C}\right)$, a guard column, three Phenomexex $5.0 \mu \mathrm{m}$ bead-size columns $\left(10^{5}, 10^{4}\right.$, and $\left.10^{3} \AA\right)$ and RID-10A refractive index detector. Dimethylformamide (DMF) containing $0.1 \% \mathrm{LiBr}$ and $0.04 \%$ 4-methoxyphenol was used as the mobile phase (flow rate $=1 \mathrm{~mL} \cdot \mathrm{min}^{-1}$ ). Molecular weights are reported relative to commercially available linear PMMA standards (Polymer Laboratories) without Mark Houwink correction. 


\section{Star RAFT agent synthesis procedure:}

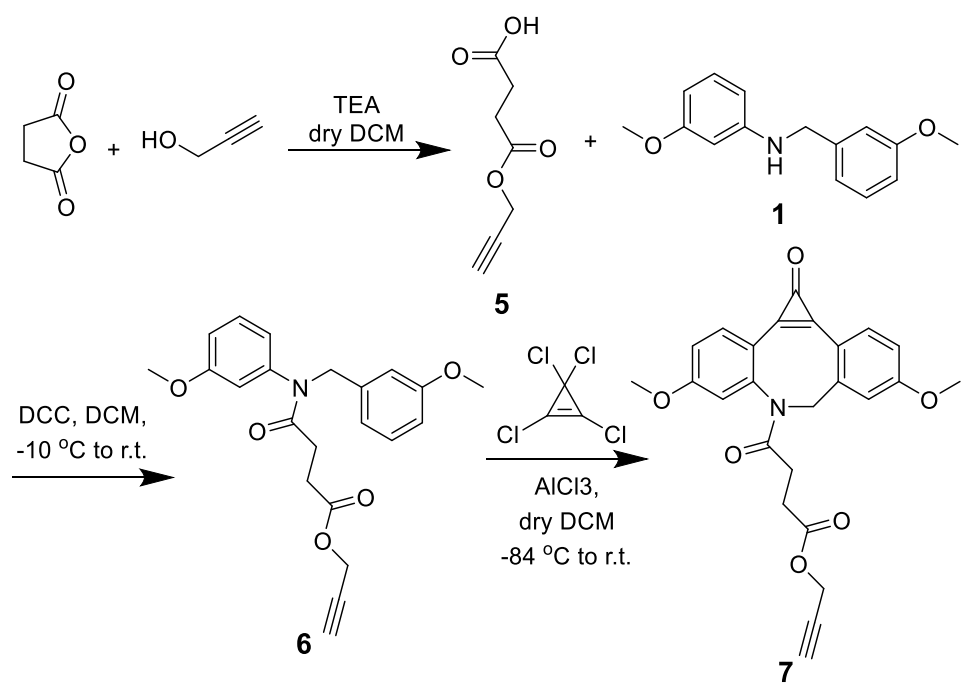

Scheme S2. Synthetic route of 7

Synthesis of 5: A mixture of succinic anhydride (12.4 g, $124 \mathrm{mmol}, 1.2 \mathrm{eq})$, propargyl alcohol (6.0 mL, $103 \mathrm{mmol}, 1 \mathrm{eq})$ and triethylamine $(15.7 \mathrm{~mL}, 113 \mathrm{mmol}, 1.1 \mathrm{eq})$ were stirred overnight in anhydrous DCM $(100 \mathrm{~mL})$ in ambient temperature. The reaction mixture was quenched with $2 \mathrm{M} \mathrm{HCl}(50 \mathrm{~mL})$. The aqueous layer was separated and extracted with DCM $(2 \times 50 \mathrm{~mL})$. The combined organic solution was washed with DI water $(100 \mathrm{~mL})$ and brine $(100 \mathrm{~mL})$ before drying with $\mathrm{MgSO}_{4}$ and concentrated with reduced pressure. The crude was purified by silica gel chromatography with EtOAc and hexane $(1: 1, \mathrm{v}: \mathrm{v})$ to yield the product $\left(11.6 \mathrm{~g}, 74.4 \mathrm{mmol}, 72.1 \%\right.$ yield). ${ }^{1} \mathrm{H}$ NMR $(300 \mathrm{MHz}$, $\left.\mathrm{CDCl}_{3}\right) \delta 4.71(\mathrm{~d}, J=2.5 \mathrm{~Hz}, 1 \mathrm{H}, \mathrm{e}), 2.77-2.62(\mathrm{~m}, 2 \mathrm{H}, \mathrm{b} \& \mathrm{c}), 2.48(\mathrm{t}, J=2.5 \mathrm{~Hz}, 1 \mathrm{H}, \mathrm{g}) .{ }^{13} \mathrm{C}$ NMR (76 $\left.\mathrm{MHz}, \mathrm{CDCl}_{3}\right) \delta 177.40$ (a), 171.48 (d), 77.51, (f), 75.22 (g), 52.47 (e), 28.76 (b\&c).

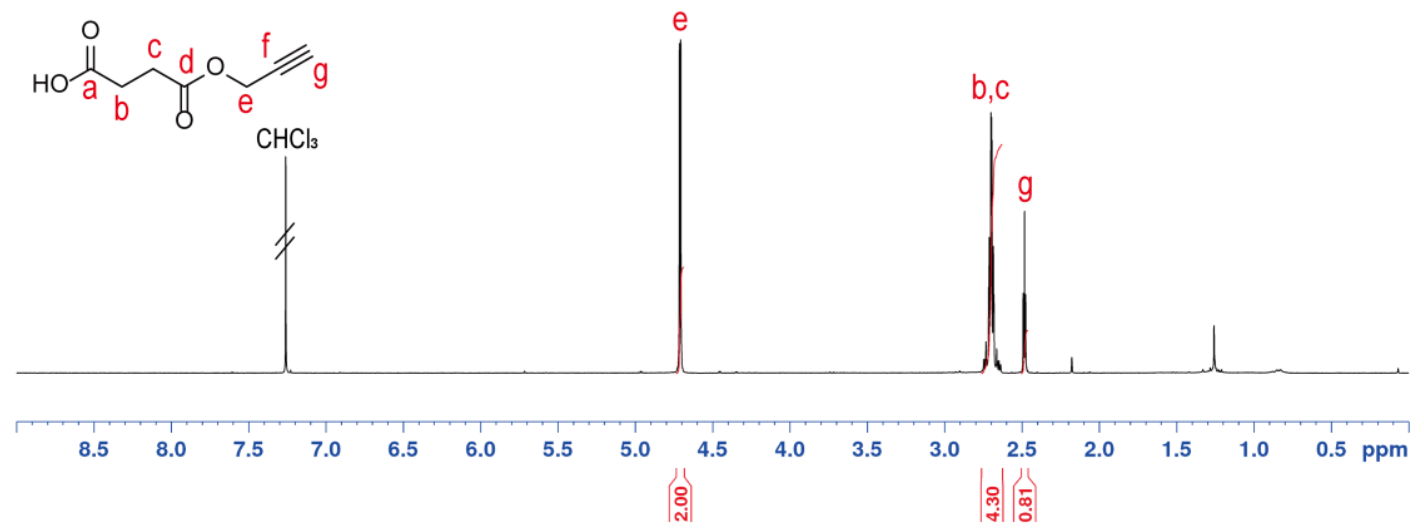

Figure S6. ${ }^{1} \mathrm{H} \mathrm{NMR}\left(300 \mathrm{MHz}, \mathrm{CDCl}_{3}\right)$ of 5

Synthesis of 6: A solution mixture of 1 (10.7 g, $44.4 \mathrm{mmol}, 1 \mathrm{eq})$ and 5 (7.63 g, $48.9 \mathrm{mmol}, 1.1 \mathrm{eq})$ in DCM $(100 \mathrm{~mL})$ was cooled to $-10{ }^{\circ} \mathrm{C}$ in an ice/acetone bath. DCC $(11.0 \mathrm{~g}, 53.3 \mathrm{mmol}, 1.5 \mathrm{eq})$ was added in one portion and stirred at $-10^{\circ} \mathrm{C}$ for $1 \mathrm{~h}$, then ambient temperature overnight. The white precipitate formed was filtered by silica and the solution mixture was diluted with DCM $(200 \mathrm{~mL})$. After washing with saturated $\mathrm{NaHCO}_{3}(3000 \mathrm{~mL})$, DI water $(3000 \mathrm{~mL})$ and brine $(300 \mathrm{~mL})$, the solution was dried with $\mathrm{MgSO}_{4}$ and concentrated under vacuum. Purification of the crude by silica gel chromatography with EtOAc and hexane $(1: 2, \mathrm{v}: \mathrm{v})$ yielded the product $(14.8 \mathrm{~g}, 38.9 \mathrm{mmol}, 87.6 \%$ yield). ${ }^{1} \mathrm{H}$ NMR (400 MHz, $\left.\mathrm{CDCl}_{3}\right) \delta 7.25-7.12(\mathrm{~m}, 3 \mathrm{H}, \mathrm{Ar}), 6.84$ (dd, $\left.J=8.3,2.0 \mathrm{~Hz}, 1 \mathrm{H}, \mathrm{Ar}\right), 6.81-$ 
$6.73(\mathrm{~m}, 3 \mathrm{H}, \mathrm{Ar}), 6.65(\mathrm{~d}, J=7.7 \mathrm{~Hz}, 1 \mathrm{H}, \mathrm{Ar}), 6.57(\mathrm{t}, J=1.9 \mathrm{~Hz}, 1 \mathrm{H}, \mathrm{Ar}), 4.84(\mathrm{~s}, J=8.3 \mathrm{~Hz}, 2 \mathrm{H}, \mathrm{b}), 4.68$ $(\mathrm{d}, J=2.5 \mathrm{~Hz}, 2 \mathrm{H}, \mathrm{d}), 3.76(\mathrm{~s}, 3 \mathrm{H}, \mathrm{c}), 3.72\left(\mathrm{~s}, 3 \mathrm{H}, \mathrm{c}^{\prime}\right), 2.69(\mathrm{t}, J=6.6 \mathrm{~Hz}, 2 \mathrm{H}, \mathrm{e}), 2.48-2.37(\mathrm{~m}, 3 \mathrm{H}, \mathrm{f} \& \mathrm{~g})$. ${ }^{13} \mathrm{C} \mathrm{NMR}\left(101 \mathrm{MHz}, \mathrm{CDCl}_{3}\right.$ ) $\delta 172.36$ (h), 171.13 (i), 160.51 (Ar), 159.77 (Ar), 143.25 (Ar), 139.15 (Ar), 130.40 (Ar), 129.45 (Ar), 121.17 (Ar), 120.78 (Ar), 114.28 (Ar), 114.08 (Ar), 113.87 (Ar), 113.27 (Ar), 77.84 (j), 74.94 (f), 55.48 (c), 55.35 (c'), 53.14 (b), 52.17 (d), 29.42 (e), 29.28 (g).

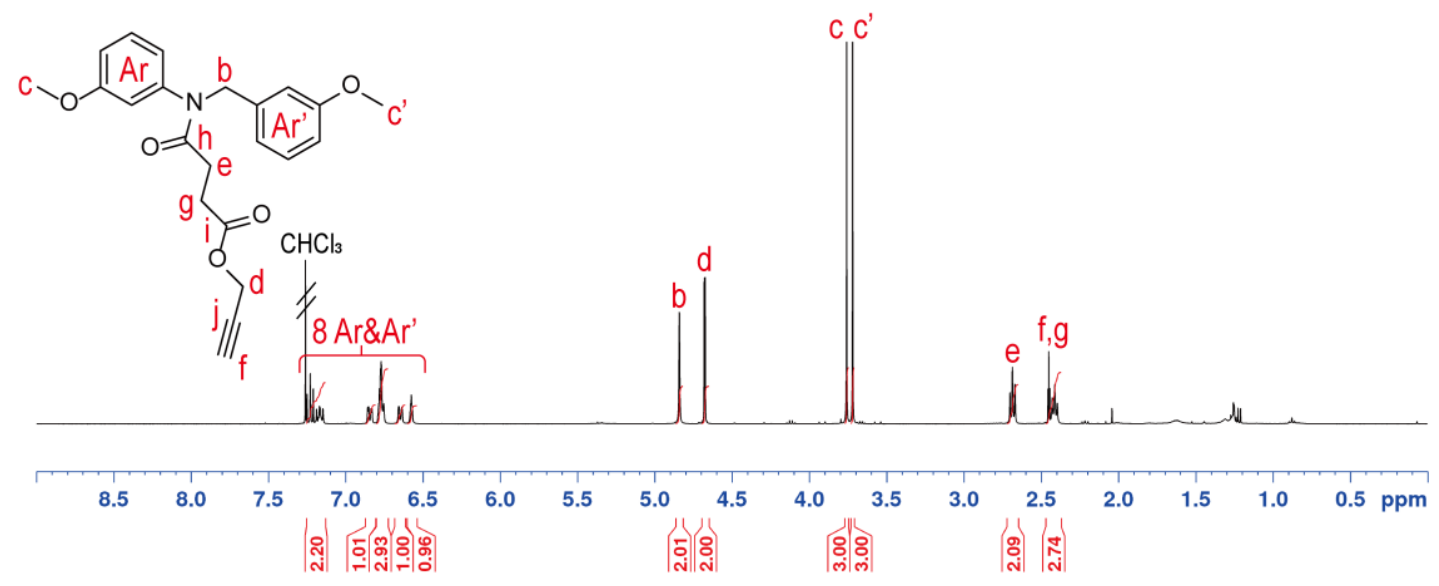

Figure S7. ${ }^{1} \mathrm{H} \mathrm{NMR}\left(400 \mathrm{MHz}, \mathrm{CDCl}_{3}\right)$ of 6

Synthesis of 7. A suspension of $\mathrm{AlCl}_{3}(4.55 \mathrm{~g}, 34.1 \mathrm{mmol}, 4 \mathrm{eq})$ in anhydrous DCM $(70 \mathrm{~mL})$ was cooled to $-84{ }^{\circ} \mathrm{C}$ in a liquid $\mathrm{N}_{2} /$ EtOAc bath. Tetrachlorocyclopropene $(1.67 \mathrm{~mL}, 13.6 \mathrm{mmol}, 1.6 \mathrm{eq})$ was introduced into the mixture in one portion and stirred at $-84{ }^{\circ} \mathrm{C}$ for $30 \mathrm{~min} .6(3.26 \mathrm{~g}, 8.55 \mathrm{mmol}, 1$ eq) was dissolved in anhydrous DCM $(20 \mathrm{~mL})$ and slowly added into the mixture over $1 \mathrm{~h}$. The reaction mixture was kept at $-84^{\circ} \mathrm{C}$ under $\mathrm{N}_{2}$ for another $1 \mathrm{~h}$ before stirring at ambient temperature overnight. After quenching the reaction with $\mathrm{HCl}(1 \mathrm{M}, 70 \mathrm{~mL})$, the separated aqueous layer was extracted with DCM $(50 \mathrm{~mL})$. The combined DCM solution was washed sequentially with $\mathrm{DI}$ water $(150 \mathrm{~mL} \times 3)$ and brine $(150 \mathrm{~mL})$ before drying with $\mathrm{MgSO}_{4}$ and concentrated under reduced pressure. Gradient silica gel chromatography with EtOAc (70 to 100\%) in hexane was performed to purify the product $\left(1.10 \mathrm{~g}, 2.55 \mathrm{mmol}, 29.9 \%\right.$ yield). ${ }^{1} \mathrm{H} \mathrm{NMR}\left(400 \mathrm{MHz}, \mathrm{CDCl}_{3}\right) \delta 8.01(\mathrm{~d}, J=8.6 \mathrm{~Hz}$, $1 \mathrm{H}, \mathrm{Ar}), 7.90(\mathrm{~d}, J=8.5 \mathrm{~Hz}, 1 \mathrm{H}, \mathrm{Ar}), 7.23(\mathrm{~d}, J=2.5 \mathrm{~Hz}, 1 \mathrm{H}, \mathrm{Ar}), 7.15(\mathrm{~d}, J=2.5 \mathrm{~Hz}, 1 \mathrm{H}, \mathrm{Ar}), 7.05$ (dd, $J=$ 8.6, $2.5 \mathrm{~Hz}, 1 \mathrm{H}, \mathrm{Ar}), 6.95(\mathrm{dd}, J=8.5,2.6 \mathrm{~Hz}, 1 \mathrm{H}, \mathrm{Ar}), 5.19\left(\mathrm{~d}, J=14.4 \mathrm{~Hz}, 1 \mathrm{H}, \mathrm{b}_{1}\right), 4.72-4.60(\mathrm{~m}, 1 \mathrm{H}$, $\left.\mathrm{d}_{1}\right), 4.51\left(\mathrm{dd}, J=15.6,2.5 \mathrm{~Hz}, 1 \mathrm{H}, \mathrm{d}_{2}\right), 4.11\left(\mathrm{~d}, J=14.1 \mathrm{~Hz}, 1 \mathrm{H}, \mathrm{b}_{1}\right), 3.93(\mathrm{~s}, 3 \mathrm{H}, \mathrm{c}), 3.90\left(\mathrm{~s}, 3 \mathrm{H}, \mathrm{c}^{\prime}\right), 2.84$ - $2.64(\mathrm{~m}, 2 \mathrm{H}, \mathrm{e}), 2.48-2.36\left(\mathrm{~m}, 2 \mathrm{H}, \mathrm{f} \& \mathrm{~g}_{1}\right), 1.99-1.89\left(\mathrm{~m}, 1 \mathrm{H}, \mathrm{g}_{2}\right) .{ }^{13} \mathrm{C} \mathrm{NMR}\left(101 \mathrm{MHz}, \mathrm{CDCl}_{3}\right) \delta$ $172.03(\mathrm{~h}), 171.82(\mathrm{i}), 163.28(\mathrm{k}), 162.82(\mathrm{l}), 152.71(\mathrm{~m}), 145.94(\mathrm{Ar}), 143.38(\mathrm{Ar}), 141.64(\mathrm{Ar}), 139.11$ (Ar), 136.03 (Ar), 135.29 (Ar), 118.24 (Ar), 115.75 (Ar), 115.54 (Ar), 115.19 (Ar), 114.47 (Ar), 113.83 (Ar), 77.62 (j), 75.13 (f), 56.40 (c), 56.13 (c'), 55.73 (b), 52.26 (d), 29.18 (e), 28.98 (g). 


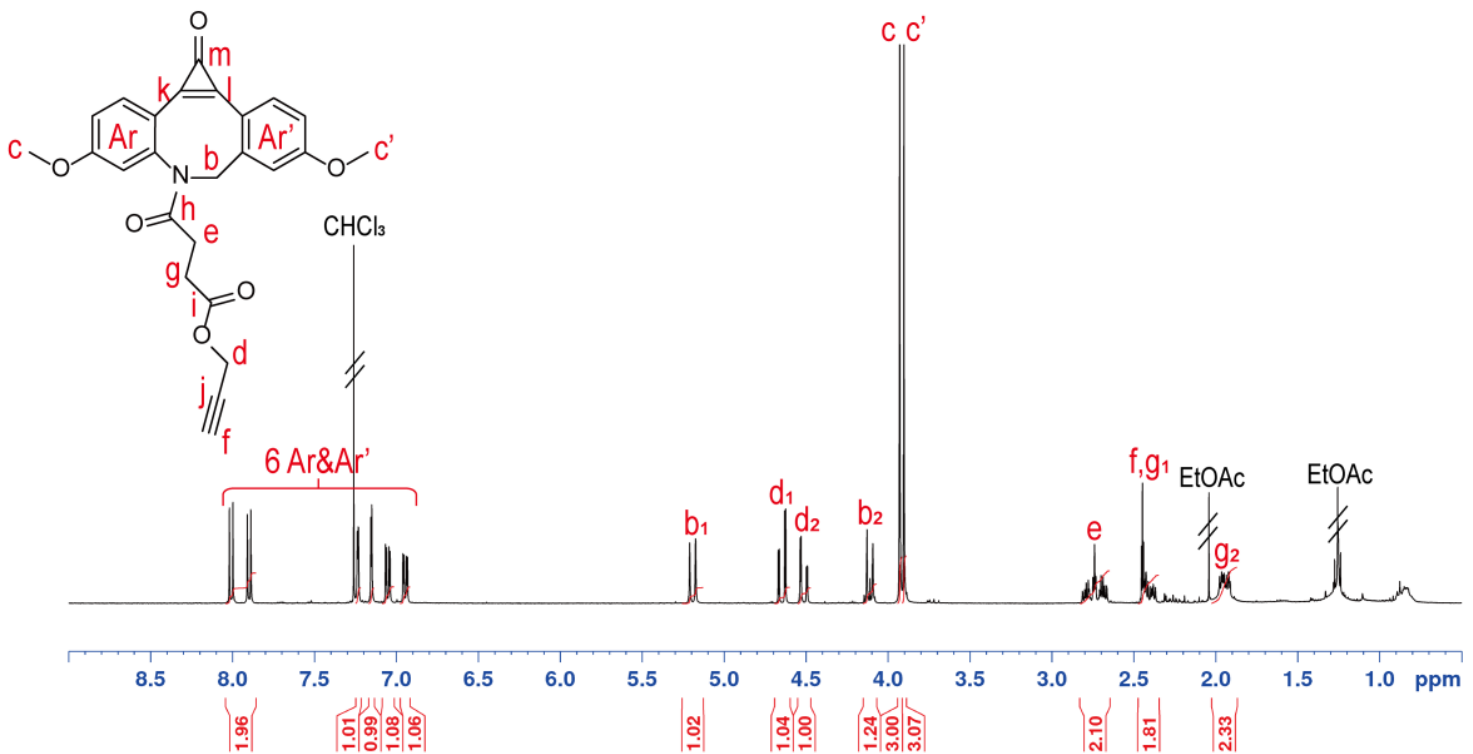

Figure S8. ${ }^{1} \mathrm{H}$ NMR $\left(400 \mathrm{MHz}, \mathrm{CDCl}_{3}\right)$ of 7

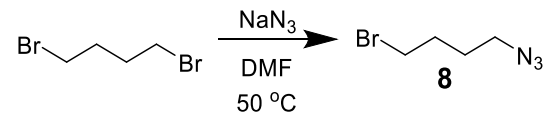

Scheme S3. Synthesis of 8

Synthesis of 8. A mixture of 1,4-dibromobutane $(8.00 \mathrm{~g}, 37.0 \mathrm{mmol}, 1.1 \mathrm{eq})$ and sodium azide $(2.16 \mathrm{~g}$, $33.3 \mathrm{mmol}, 1 \mathrm{eq})$ in DMF (60 mL) was stirred at $50{ }^{\circ} \mathrm{C}$ overnight. After quenching the reaction with ice, the mixture was extracted with EtOAc $(3 \times 100 \mathrm{~mL})$. The combined organic solution was washed with DI water $(300 \mathrm{~mL})$ and brine $(300 \mathrm{~mL})$, then dried with $\mathrm{MgSO}_{4}$ and concentrated under vacuum. The crude was purified by gradient silica gel chromatography with EtOAc (0 to 5\%) in hexane to obtain the product $\left(1.63 \mathrm{~g}, 9.18 \mathrm{mmol}, 24.8 \%\right.$ yield). ${ }^{1} \mathrm{H} \mathrm{NMR}\left(300 \mathrm{MHz}, \mathrm{CDCl}_{3}\right) \delta 3.43(\mathrm{t}, J=6.5 \mathrm{~Hz}$, $2 \mathrm{H}, \mathrm{a}), 3.33(\mathrm{t}, J=6.6 \mathrm{~Hz}, 2 \mathrm{H}, \mathrm{d}), 2.01-1.88(\mathrm{~m}, 2 \mathrm{H}, \mathrm{b}), 1.82-1.70(\mathrm{~m}, 2 \mathrm{H}, \mathrm{c}) .{ }^{13} \mathrm{C} N M R(76 \mathrm{MHz}$, $\left.\mathrm{CDCl}_{3}\right) \delta 50.73$ (d), 32.99 (a), 29.90 (b), 27.61 (c).

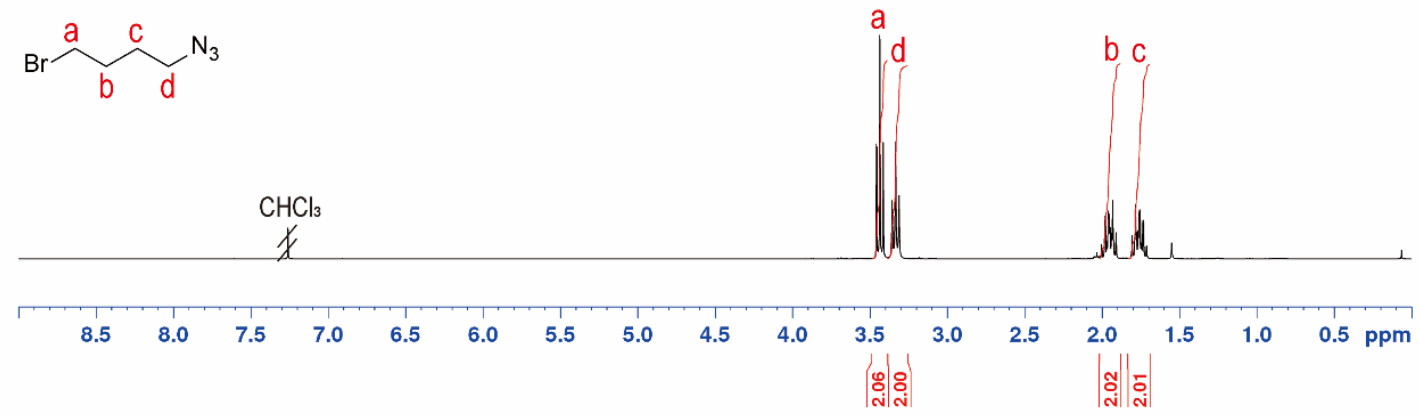

Figure S9. ${ }^{1} \mathrm{H}$ NMR $\left(300 \mathrm{MHz}, \mathrm{CDCl}_{3}\right)$ of 8 


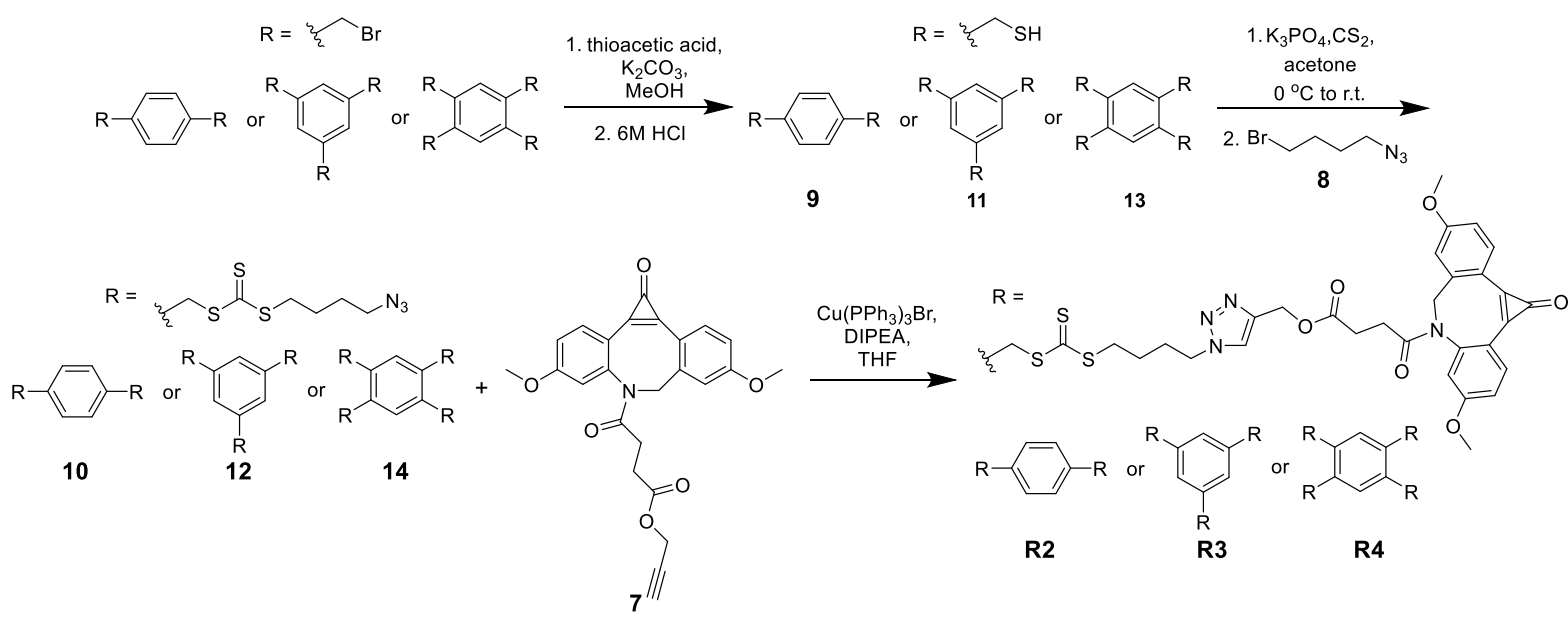

Scheme S4. Synthetic route of multiarmed RAFT agents

Synthesis of $\mathbf{9}$. 9 was synthesised by following a procedure adapted from a previous publication. ${ }^{1} \mathrm{~A}$ suspension of 1,4-bis(bromomethyl)benzene $(1.00 \mathrm{~g}, 3.81 \mathrm{mmol}, 1 \mathrm{eq})$, thioacetic acid (650 $\mu \mathrm{L}, 9.10$ mmol, 2.4 eq) and $\mathrm{K}_{2} \mathrm{CO}_{3}(1.26 \mathrm{~g}, 9.10 \mathrm{mmol}, 2.4 \mathrm{eq})$ in $\mathrm{MeOH}(12 \mathrm{~mL})$ was stirred at ambient temperature for $30 \mathrm{~min}$. Another portion of $\mathrm{K}_{2} \mathrm{CO}_{3}(1.26 \mathrm{~g}, 9.10 \mathrm{mmol}, 2.4 \mathrm{eq})$ was added and the mixture was stirred for 30 min before acidification with $6 \mathrm{M} \mathrm{HCl}$ to $\mathrm{pH} 4$. The mixture was diluted with DI water $(50 \mathrm{~mL})$ and extracted with $\mathrm{CHCl}_{3}(3 \times 50 \mathrm{~mL})$. The combined $\mathrm{CHCl}_{3}$ layer was dried with $\mathrm{MgSO}_{4}$, followed by the removal of solvent under reduced pressure to yield the product $(659 \mathrm{mg}$, $3.87 \mathrm{mmol}$, quantitative yield). The product was used for later synthesis without further purification. ${ }^{1} \mathrm{H} \mathrm{NMR}\left(400 \mathrm{MHz}, \mathrm{CDCl}_{3}\right) \delta 7.28(\mathrm{~s}, 3 \mathrm{H}, \mathrm{a}), 3.73(\mathrm{~d}, J=7.5 \mathrm{~Hz}, 5 \mathrm{H}, \mathrm{b}), 1.75(\mathrm{t}, J=7.5 \mathrm{~Hz}, 2 \mathrm{H}, \mathrm{c})$.

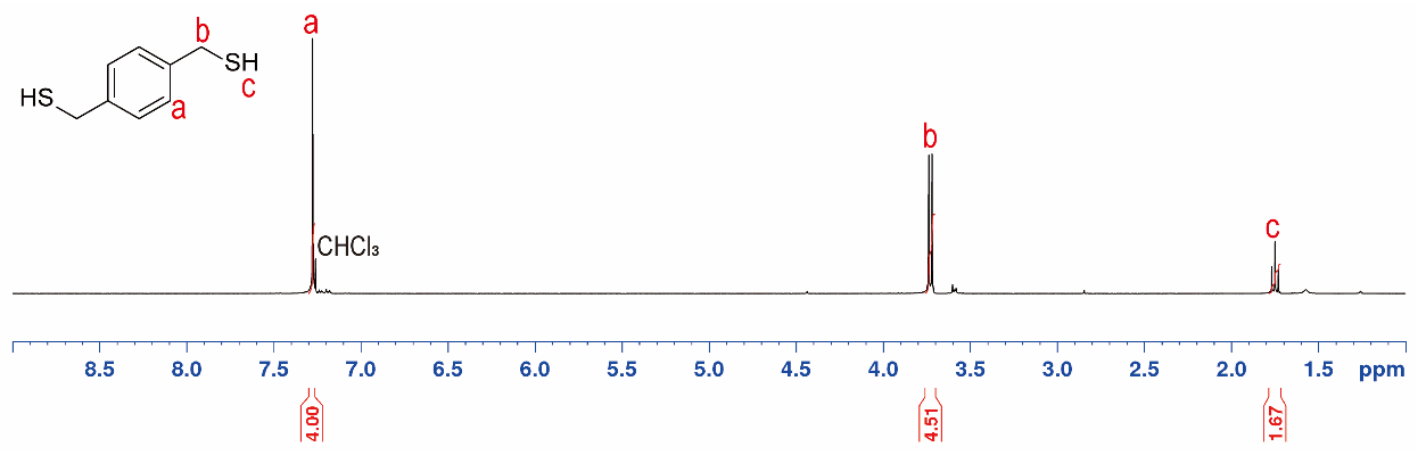

Figure $\mathrm{S} 10 .{ }^{1} \mathrm{H} \mathrm{NMR}\left(400 \mathrm{MHz}, \mathrm{CDCl}_{3}\right)$ of 9

Synthesis of 10. To an ice-bath-cooled suspension of 9 (734 mg, $4.31 \mathrm{mmol}, 1 \mathrm{eq})$ and $\mathrm{K}_{3} \mathrm{PO}_{4}(1.83 \mathrm{~g}$, $8.62 \mathrm{mmol}, 2 \mathrm{eq})$ in acetone $(35 \mathrm{~mL})$ was added $\mathrm{CS}_{2}(780 \mu \mathrm{L}, 12.9 \mathrm{mmol}, 3 \mathrm{eq})$ in one portion. The mixture was stirred in ambient temperature for 30 min and followed by the addition of $8(1.69 \mathrm{~g}$, $9.48 \mathrm{mmol}, 2.2 \mathrm{eq}$ ) in one portion. The reaction mixture was stirred overnight and diluted with DCM $(50 \mathrm{~mL})$ before washing with $0.1 \mathrm{M} \mathrm{HCl}(2 \times 50 \mathrm{~mL})$, DI water $(50 \mathrm{~mL})$ and brine $(50 \mathrm{~mL})$. The organic solution was dried with $\mathrm{MgSO}_{4}$ and concentrated under vacuum. Silica gel chromatography with EtOAc (10\%) in hexane was performed to purify the product $\left(1.44 \mathrm{~g}, 2.78 \mathrm{mmol}, 64.4 \%\right.$ yield). ${ }^{1} \mathrm{H}$ NMR (400 MHz, CDCl $\left.)_{3}\right) \quad 7.28\left(\mathrm{~s}, 4 \mathrm{H}, \mathrm{a}_{1}\right), 4.59(\mathrm{~s}, 4 \mathrm{H}, \mathrm{b}), 3.40(\mathrm{t}, J=7.2 \mathrm{~Hz}, 4 \mathrm{H}, \mathrm{c}), 3.32(\mathrm{t}, J=6.6 \mathrm{~Hz}$, $4 \mathrm{H}, \mathrm{f}), 1.85-1.75(\mathrm{~m}, 4 \mathrm{H}, \mathrm{d}), 1.75-1.66(\mathrm{~m}, 4 \mathrm{H}, \mathrm{e}) .{ }^{13} \mathrm{C} \mathrm{NMR}\left(76 \mathrm{MHz}, \mathrm{CDCl}_{3}\right) \delta 134.85\left(\mathrm{a}_{2}\right), 129.69$ $\left(a_{1}\right), 50.98$ (f), 41.04 (b), 36.31 (c), 28.16 (e), 25.60 (d). 


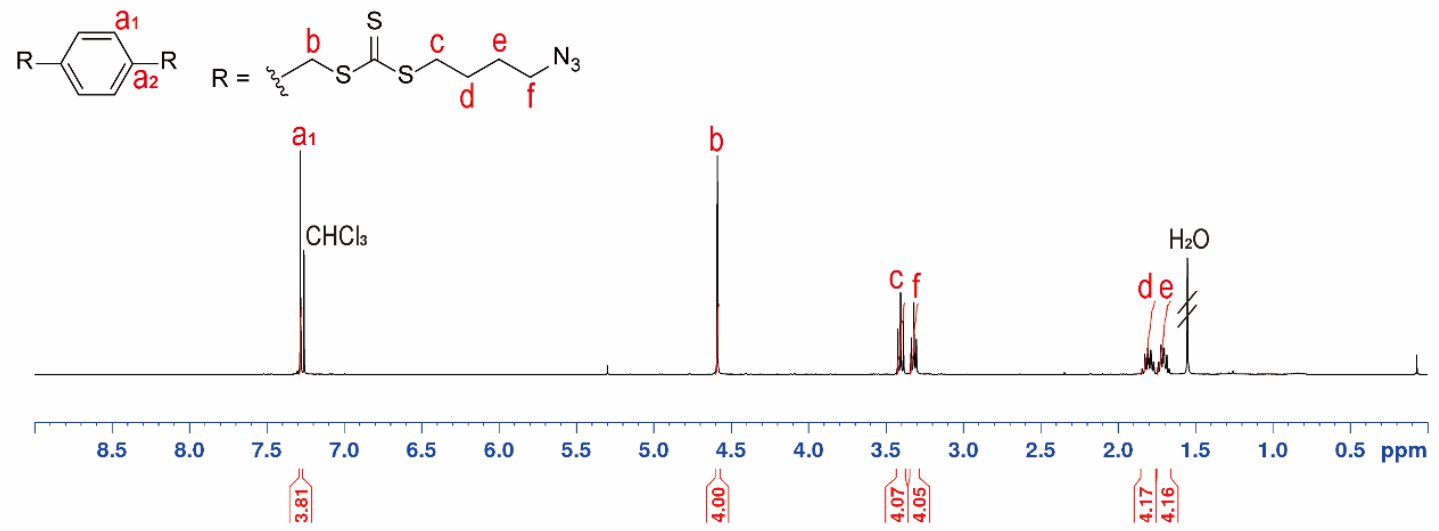

Figure S11. ${ }^{1} \mathrm{H}$ NMR $\left(400 \mathrm{MHz}, \mathrm{CDCl}_{3}\right)$ of 10

Synthesis of $\boldsymbol{R 2}$. A solution of $\mathbf{1 0}(27.2 \mathrm{mg}, 52.7 \mu \mathrm{mol}, 1 \mathrm{eq}), \mathbf{7}(50.0 \mathrm{mg}, 116 \mu \mathrm{mol}, 2.2 \mathrm{eq})$ and DIPEA $(4.6 \mu \mathrm{L}, 26.4 \mu \mathrm{mol}, 0.5 \mathrm{eq})$ in THF was purged with nitrogen for $20 \mathrm{~min}$. $\mathrm{Cu}\left(\mathrm{PPh}_{3}\right)_{3} \mathrm{Br}(4.9 \mathrm{mg}, 5.27$ $\mu \mathrm{mol}, 0.1 \mathrm{eq})$ was suspended in THF ( $0.1 \mathrm{~mL}$, purged with nitrogen) and added to the solution. The reaction mixture was purged with nitrogen for another $5 \mathrm{~min}$, followed by stirring in ambient temperature under nitrogen for 2 days. The mixture was diluted with $\mathrm{CHCl}_{3}(50 \mathrm{~mL})$, washed with 0.1 $\mathrm{M} \mathrm{HCl}(30 \mathrm{~mL})$, DI water $(30 \mathrm{~mL})$ and brine $(30 \mathrm{~mL})$ and then dried with $\mathrm{MgSO}_{4}$. The crude obtained after solvent evaporation was purified by gradient silica gel chromatography with $\mathrm{MeOH}(1-4 \%)$ in DCM to yield the product (43.5 mg, $31.5 \mu \mathrm{mol}, 59.8 \%$ yield). ${ }^{1} \mathrm{H}$ NMR $(400 \mathrm{MHz}, d 6-\mathrm{DMSO}) \delta 8.02$ (s, $2 \mathrm{H}, \mathrm{Ar}$ ), 7.91 (d, $J=8.6 \mathrm{~Hz}, 2 \mathrm{H}, \mathrm{Ar}), 7.74(\mathrm{~d}, J=8.4 \mathrm{~Hz}, 2 \mathrm{H}, \mathrm{Ar}), 7.35-7.22(\mathrm{~m}, 8 \mathrm{H}, \mathrm{Ar}), 7.18$ (dd, $J=8.6$, $2.4 \mathrm{~Hz}, 2 \mathrm{H}, \mathrm{Ar}), 7.05(\mathrm{dd}, J=8.4,2.5 \mathrm{~Hz}, 2 \mathrm{H}, \mathrm{Ar}), 4.98\left(\mathrm{~m}, 6 \mathrm{H}, \mathrm{b}_{1} \& \mathrm{~d}\right), 4.62(\mathrm{~s}, 4 \mathrm{H}, \mathrm{k}), 4.35(\mathrm{t}, J=7.0 \mathrm{~Hz}$, $4 \mathrm{H}, \mathrm{i}), 4.23\left(\mathrm{~d}, J=14.3 \mathrm{~Hz}, 2 \mathrm{H}, \mathrm{b}_{2}\right), 3.89(\mathrm{~s}, 6 \mathrm{H}, \mathrm{c}), 3.87\left(\mathrm{~s}, 6 \mathrm{H}, \mathrm{c}^{\prime}\right), 3.39(\mathrm{t}, J=7.3 \mathrm{~Hz}, 4 \mathrm{H}, \mathrm{j}), 2.70-2.59$ $\left(\mathrm{m}, 2 \mathrm{H}, \mathrm{e}_{1}\right), 2.44-2.27(\mathrm{~m}, 4 \mathrm{H}, \mathrm{f}), 1.94-1.82\left(\mathrm{~m}, 6 \mathrm{H} \mathrm{e}_{2} \& \mathrm{~h}\right), 1.66-1.55(\mathrm{~m}, 4 \mathrm{H}, \mathrm{g}) .{ }^{13} \mathrm{C}$ NMR $(101 \mathrm{MHz}$, d6-DMSO) $\delta 171.84(\mathrm{~m}), 170.87$ (I), 162.65 (o), 161.80 (n), 151.07 (p), 145.71 (Ar), 142.57 (Ar), 142.27 (Ar), $141.70(\mathrm{Ar}), 139.34(\mathrm{Ar}), 134.93$ (Ar), $134.70(\mathrm{Ar}), 134.38(\mathrm{Ar}), 129.47(\mathrm{Ar}), 124.52$ (Ar), 118.46 (Ar), 115.57 (Ar), $115.36(\mathrm{Ar}), 114.67$ (Ar), 114.49 (Ar), 113.09 (Ar), 57.18 (d), 56.07 (b), 55.83 (c), $55.67\left(c^{\prime}\right), 40.19(k), 48.74$ (i), 35.62 (j), 29.60 (e), 28.79 (f), 28.71 (h), 24.72 (g).

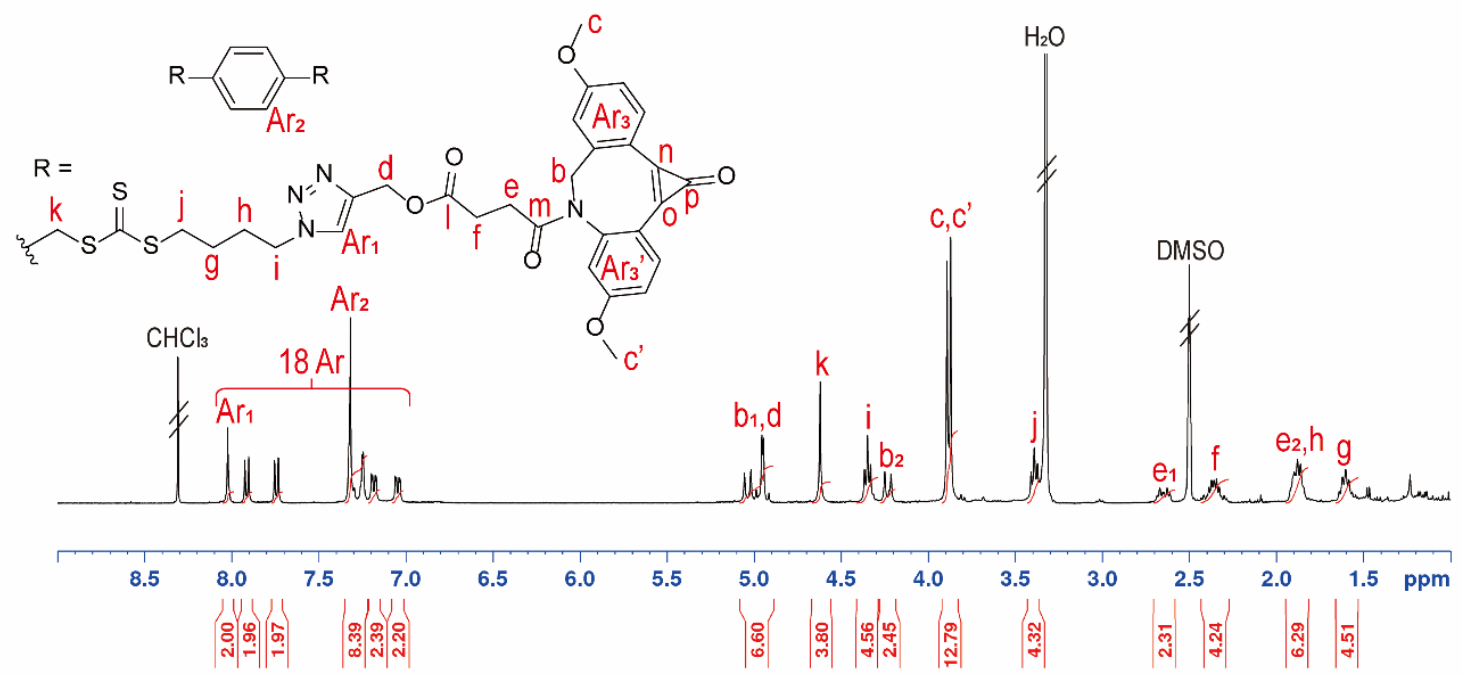

Figure S12. ${ }^{1} \mathrm{H}$ NMR (400 MHz, d6-DMSO) of R2

Synthesis of 11. 11 was synthesised and purified ( $94.8 \%$ yield) under the same conditions as for the synthesis of 9 while keeping ratio of number of arm : thioacetic acid : $\mathrm{K}_{2} \mathrm{CO}_{3}$ as $1: 1.5: 1.5 .{ }^{1} \mathrm{H} \mathrm{NMR}$ $\left(400 \mathrm{MHz}, \mathrm{CDCl}_{3}\right) \delta 7.17(\mathrm{~s}, J=5.4 \mathrm{~Hz}, 3 \mathrm{H}, \mathrm{a}), 3.72(\mathrm{~d}, J=7.6 \mathrm{~Hz}, 6 \mathrm{H}, \mathrm{b}), 1.78(\mathrm{t}, J=7.6 \mathrm{~Hz}, 3 \mathrm{H}, \mathrm{c})$. 


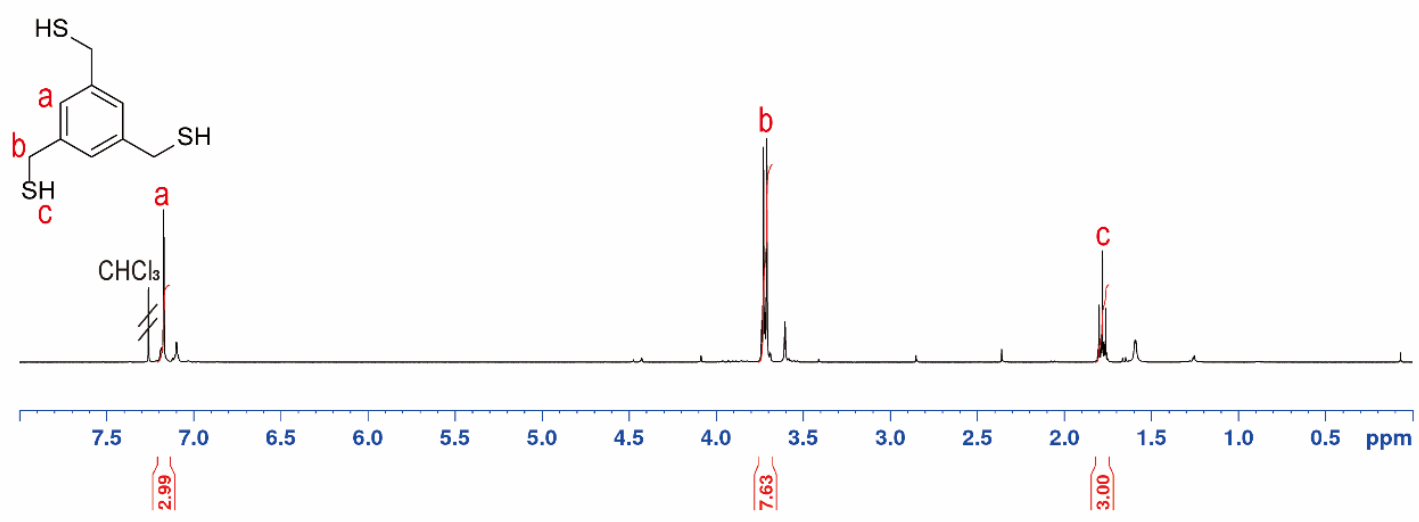

Figure S13. ${ }^{1} \mathrm{H}$ NMR $\left(400 \mathrm{MHz}, \mathrm{CDCl}_{3}\right)$ of 11

Synthesis of 12. 12 was synthesised and purified (57.6\% yield) under the same conditions as for the synthesis of 10 while keeping ratio of number of arm : $\mathrm{K}_{3} \mathrm{PO}_{4}: \mathrm{CS}_{2}: 8$ as $1: 1: 1.5: 1.2 .{ }^{1} \mathrm{H}$ NMR (400 $\left.\mathrm{MHz}, \mathrm{CDCl}_{3}\right) \delta 7.21\left(\mathrm{~s}, 3 \mathrm{H}, \mathrm{a}_{1}\right), 4.55(\mathrm{~s}, 6 \mathrm{H}, \mathrm{b}), 3.41(\mathrm{t}, J=7.2 \mathrm{~Hz}, 6 \mathrm{H}, \mathrm{c}), 3.33(\mathrm{t}, J=6.6 \mathrm{~Hz}, 6 \mathrm{H}, \mathrm{f}), 1.86-$ $1.75(\mathrm{~m}, 6 \mathrm{H}, \mathrm{d}), 1.76-1.66(\mathrm{~m}, 6 \mathrm{H}, \mathrm{e}) .{ }^{13} \mathrm{C}$ NMR $\left(101 \mathrm{MHz}, \mathrm{CDCl}_{3}\right) \delta 136.44\left(\mathrm{a}_{2}\right), 129.61\left(\mathrm{a}_{1}\right), 51.01(\mathrm{f})$, 40.87 (b), 36.39 (c), 28.19 (e), 25.61 (d).

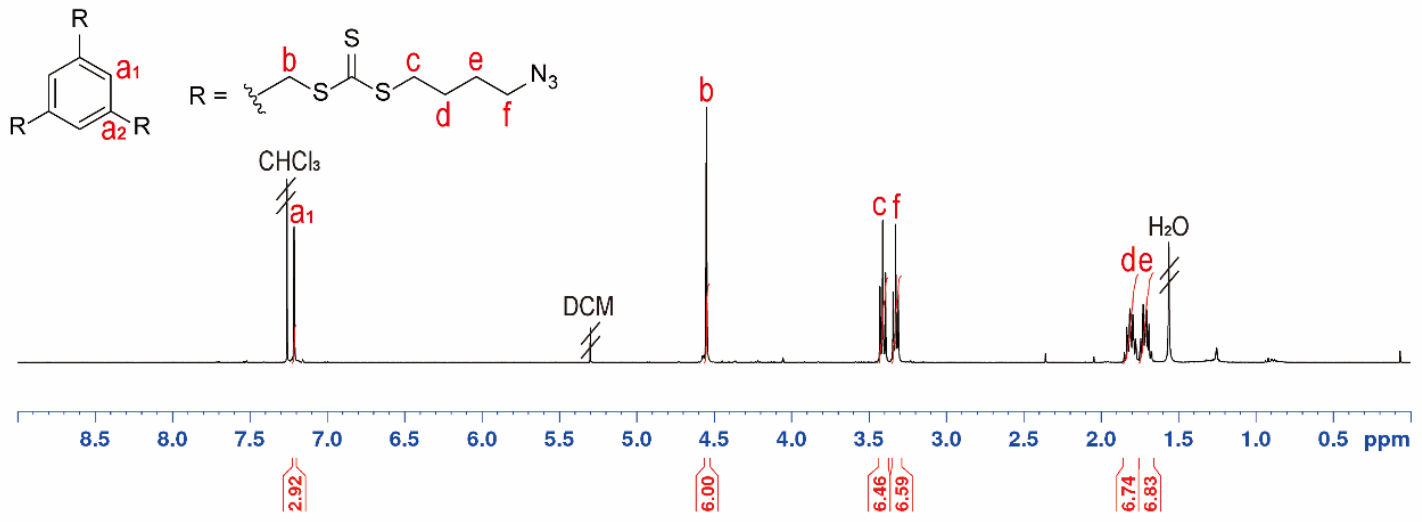

Figure S14. ${ }^{1} \mathrm{H}$ NMR $\left(400 \mathrm{MHz}, \mathrm{CDCl}_{3}\right)$ of 12

Synthesis of $\mathbf{R} \mathbf{3}$. $\mathbf{R} \mathbf{3}$ was synthesised and purified ( $25.8 \%$ yield) under the same conditions as for the synthesis of $\mathbf{R 2}$ while keeping ratio of number of arm : 7 : DIPEA : $\mathrm{Cu}\left(\mathrm{PPh}_{3}\right)_{3} \mathrm{Br}$ as $1: 1.1: 0.25: 0.05$. ${ }^{1} \mathrm{H} \mathrm{NMR}(400 \mathrm{MHz}, d 6-\mathrm{DMSO}) \delta 8.02(\mathrm{~s}, 3 \mathrm{H}, \mathrm{Ar}), 7.91$ (d, $\left.J=8.6 \mathrm{~Hz}, 3 \mathrm{H}, \mathrm{Ar}\right), 7.74(\mathrm{~d}, J=8.5 \mathrm{~Hz}, 3 \mathrm{H}, \mathrm{Ar})$, $7.32(\mathrm{~d}, J=2.5 \mathrm{~Hz}, 3 \mathrm{H}, \mathrm{Ar}), 7.29(\mathrm{~s}, 3 \mathrm{H}, \mathrm{Ar}), 7.24(\mathrm{~d}, J=2.5 \mathrm{~Hz}, 3 \mathrm{H}, \mathrm{Ar}), 7.18$ (dd, $J=8.6,2.5 \mathrm{~Hz}, 3 \mathrm{H}, \mathrm{Ar}$ ), $7.04(\mathrm{dd}, J=8.5,2.6 \mathrm{~Hz}, 3 \mathrm{H}, \mathrm{Ar}), 5.07-4.88\left(\mathrm{~m}, 9 \mathrm{H}, \mathrm{b}_{1} \& \mathrm{~d}\right), 4.59(\mathrm{~s}, 6 \mathrm{H}, \mathrm{k}), 4.34(\mathrm{t}, J=7.0 \mathrm{~Hz}, 6 \mathrm{H}, \mathrm{i})$, $4.23\left(\mathrm{~d}, J=14.5 \mathrm{~Hz}, 3 \mathrm{H}, \mathrm{b}_{2}\right), 3.88(\mathrm{~s}, 9 \mathrm{H}, \mathrm{c}), 3.86\left(\mathrm{~s}, 9 \mathrm{H}, \mathrm{c}^{\prime}\right), 3.38(\mathrm{t}, J=7.3 \mathrm{~Hz}, 6 \mathrm{H}, \mathrm{j}), 2.70-2.59(\mathrm{~m}, 3 \mathrm{H}$, $\left.\mathrm{e}_{1}\right), 2.43-2.27(\mathrm{~m}, 6 \mathrm{H}, \mathrm{f}), 1.93-1.82\left(\mathrm{~m}, 9 \mathrm{H}, \mathrm{e}_{2} \& \mathrm{~h}\right), 1.65-1.52(\mathrm{~m}, 6 \mathrm{H}, \mathrm{g}) .{ }^{13} \mathrm{C} N M R(101 \mathrm{MHz}, d 6-$ DMSO) $\delta 171.86$ (m), 170.89 (I), 162.64 (o), 161.80 (n), 151.07 (p), 145.71 (Ar), 142.57 (Ar), 142.28 (Ar), 141.70 (Ar), 139.34 (Ar), 136.23 (Ar), 134.94 (Ar), 134.39 (Ar), 129.27 (Ar), 124.53 (Ar), 118.47 (Ar), 115.59 (Ar), 115.37 (Ar), $114.68(\mathrm{Ar}), 114.49(\mathrm{Ar}), 113.08(\mathrm{Ar}), 57.19$ (d), 56.08 (b), 55.67 (c), $55.32\left(c^{\prime}\right), 40.19$ (k), 48.76 (i), 35.69 (j), 28.86 (e), 28.81 (f), 28.71 (h), 24.72 (g). 


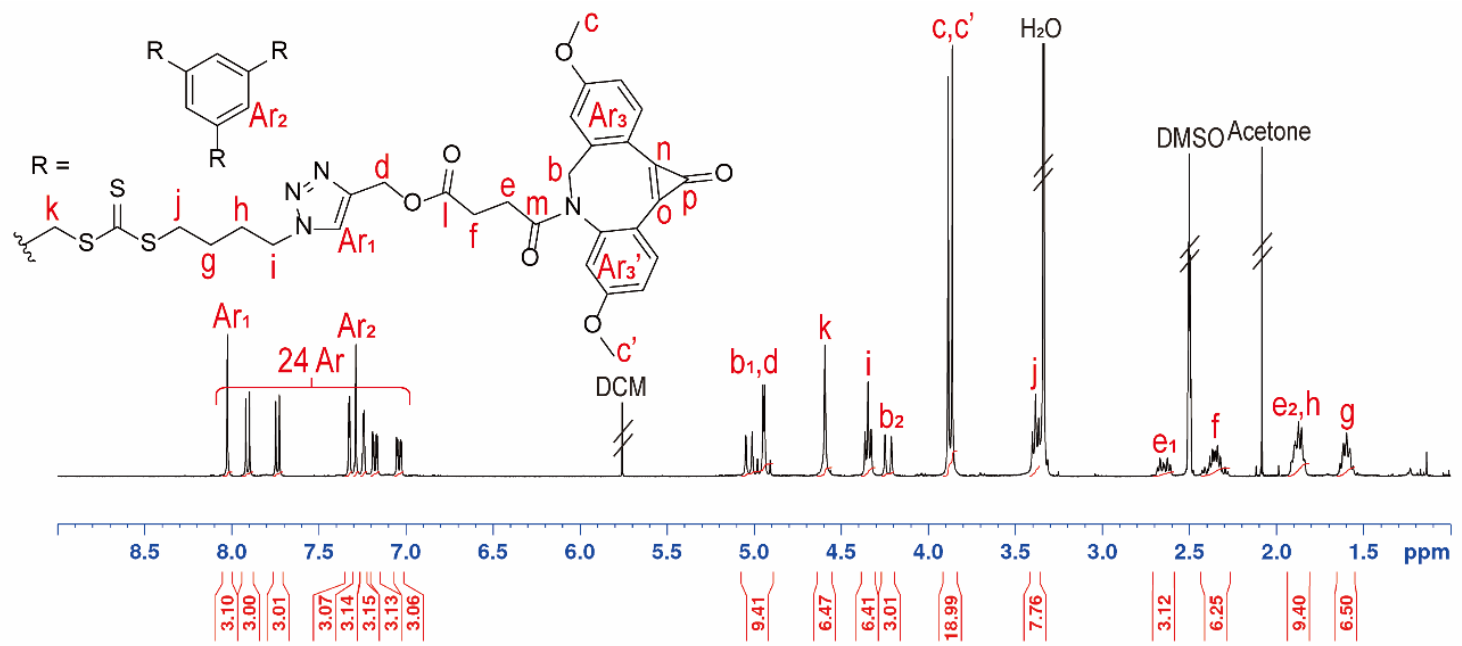

Figure S15. ${ }^{1} \mathrm{H}$ NMR (400 MHz, d6-DMSO) of R3

Synthesis of 13. 13 was synthesised and purified (quantitative yield) under the same conditions as for the synthesis of 9 while keeping ratio of number of arm : thioacetic acid : $\mathrm{K}_{2} \mathrm{CO}_{3}$ as $1: 1.5: 1.5 .{ }^{1} \mathrm{H}$ $\operatorname{NMR}\left(400 \mathrm{MHz}, \mathrm{CDCl}_{3}\right) \delta 7.20(\mathrm{~s}, 2 \mathrm{H}), 3.82(\mathrm{~d}, J=7.2 \mathrm{~Hz}, 8 \mathrm{H}), 1.86(\mathrm{t}, J=7.2 \mathrm{~Hz}, 4 \mathrm{H})$.

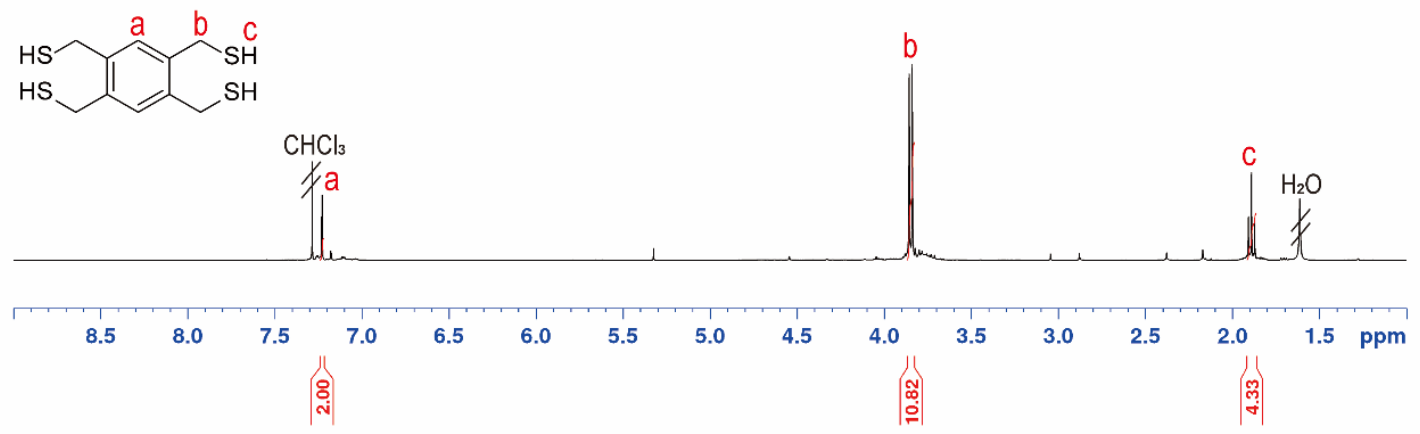

Figure S16. ${ }^{1} \mathrm{H} \mathrm{NMR}\left(400 \mathrm{MHz}, \mathrm{CDCl}_{3}\right)$ of 13

Synthesis of 14. 14 was synthesised and purified (57.6\% yield) under the same conditions as for the synthesis of 10 while keeping ratio of number of arm : $\mathrm{K}_{3} \mathrm{PO}_{4}: \mathrm{CS}_{2}: 8$ as $1: 1: 1.5: 1.2 .{ }^{1} \mathrm{H}$ NMR (400 $\left.\mathrm{MHz}, \mathrm{CDCl}_{3}\right) \delta 7.36\left(\mathrm{~s}, 2 \mathrm{H}, \mathrm{a}_{1}\right), 4.61(\mathrm{~s}, 8 \mathrm{H}, \mathrm{b}), 3.41(\mathrm{t}, J=7.2 \mathrm{~Hz}, 8 \mathrm{H}, \mathrm{c}), 3.33(\mathrm{t}, J=6.6 \mathrm{~Hz}, 8 \mathrm{H}, \mathrm{f}), 1.86-$ $1.76(\mathrm{~m}, 8 \mathrm{H}, \mathrm{d}), 1.76-1.66(\mathrm{~m}, 8 \mathrm{H}, \mathrm{e}) .{ }^{13} \mathrm{C} \mathrm{NMR}\left(101 \mathrm{MHz}, \mathrm{CDCl}_{3}\right) \delta 134.35\left(\mathrm{a}_{2}\right), 133.65\left(\mathrm{a}_{1}\right), 51.01(\mathrm{f})$, 38.46 (b), 36.47 (c), 28.20 (e), 25.62 (d).

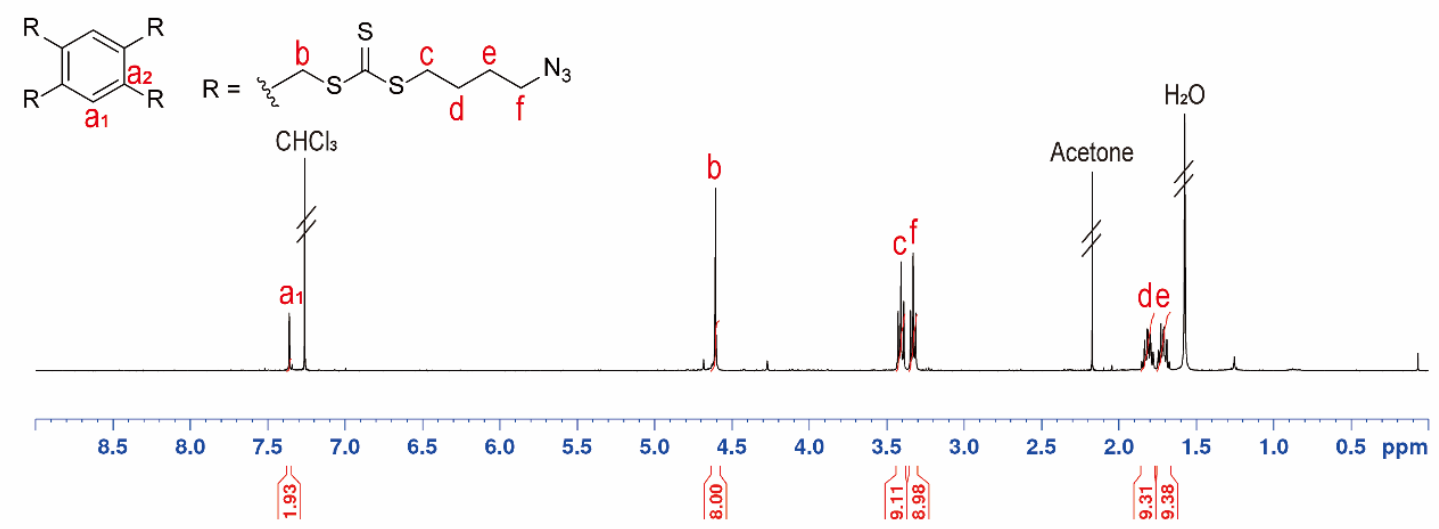

Figure S17. ${ }^{1} \mathrm{H}$ NMR $\left(400 \mathrm{MHz}, \mathrm{CDCl}_{3}\right)$ of 14

Synthesis of $\mathbf{R 4}$. R4 was synthesised and purified (19.0\% yield) under the same conditions as for the synthesis of $\mathbf{R} \mathbf{2}$ while keeping ratio of number of arm : 7 : DIPEA : $\mathrm{Cu}\left(\mathrm{PPh}_{3}\right)_{3} \mathrm{Br}$ as $1: 1.1: 0.25: 0.05$. 
${ }^{1} \mathrm{H}$ NMR (400 MHz, d6-DMSO) $\delta 8.02(\mathrm{~s}, 4 \mathrm{H}, \mathrm{Ar}), 7.90$ (d, $\left.J=8.6 \mathrm{~Hz}, 4 \mathrm{H}, \mathrm{Ar}\right), 7.73$ (d, $J=8.5 \mathrm{~Hz}, 4 \mathrm{H}, \mathrm{Ar}$ ), $7.47(\mathrm{~s}, 2 \mathrm{H}, \mathrm{Ar}$ ), 7.32 (d, J = 2.4 Hz, 4H, Ar), 7.23 (d, J=2.5 Hz, 4H, Ar), 7.17 (dd, J = 8.6, 2.5 Hz, 4H, Ar), $7.03(\mathrm{dd}, J=8.5,2.6 \mathrm{~Hz}, 4 \mathrm{H}, \mathrm{Ar}), 4.97\left(\mathrm{dt}, J=16.3,13.7 \mathrm{~Hz}, 12 \mathrm{H}, \mathrm{b}_{1} \& \mathrm{~d}\right), 4.65(\mathrm{~s}, 8 \mathrm{H}, \mathrm{k}), 4.34(\mathrm{t}, J=7.0$ $\mathrm{Hz}, 8 \mathrm{H}, \mathrm{i}), 4.22\left(\mathrm{~d}, J=14.5 \mathrm{~Hz}, 4 \mathrm{H}, \mathrm{b}_{2}\right), 3.88(\mathrm{~s}, 12 \mathrm{H}, \mathrm{c}), 3.85\left(\mathrm{~s}, 12 \mathrm{H}, \mathrm{c}^{\prime}\right), 3.38(\mathrm{t}, J=7.3 \mathrm{~Hz}, 8 \mathrm{H}, \mathrm{j}), 2.69$ $-2.59\left(\mathrm{~m}, 4 \mathrm{H}, \mathrm{e}_{1}\right), 2.43-2.26(\mathrm{~m}, 8 \mathrm{H}, \mathrm{f}), 1.94-1.81\left(\mathrm{~m}, 12 \mathrm{H}, \mathrm{e}_{2} \& \mathrm{~h}\right), 1.66-1.54(\mathrm{~m}, 8 \mathrm{H}, \mathrm{g}) .{ }^{13} \mathrm{C} N M R$ (101 MHz, d6-DMSO) $\delta 171.86$ (m), 170.89 (l), 162.64 (o), 161.80 (n), 151.07 (p), 145.70 (Ar), 142.57 (Ar), 142.27 (Ar), $141.71(\mathrm{Ar}), 139.34(\mathrm{Ar}), 134.94(\mathrm{Ar}), 134.39$ (Ar), $133.92(\mathrm{Ar}), 130.44(\mathrm{Ar}), 124.52$ (Ar), $118.46(\mathrm{Ar}), 115.58(\mathrm{Ar}), 115.36(\mathrm{Ar}), 114.67(\mathrm{Ar}), 114.48(\mathrm{Ar}), 113.07(\mathrm{Ar}), 57.19(\mathrm{~d}), 56.07$ (b), 55.66 (c), $55.32\left(c^{\prime}\right), 48.76$ (i), 37.53 (k), 35.77 (i), 28.87 (e), 28.81 (f), 28.71 (h), $24.73(\mathrm{~g})$.

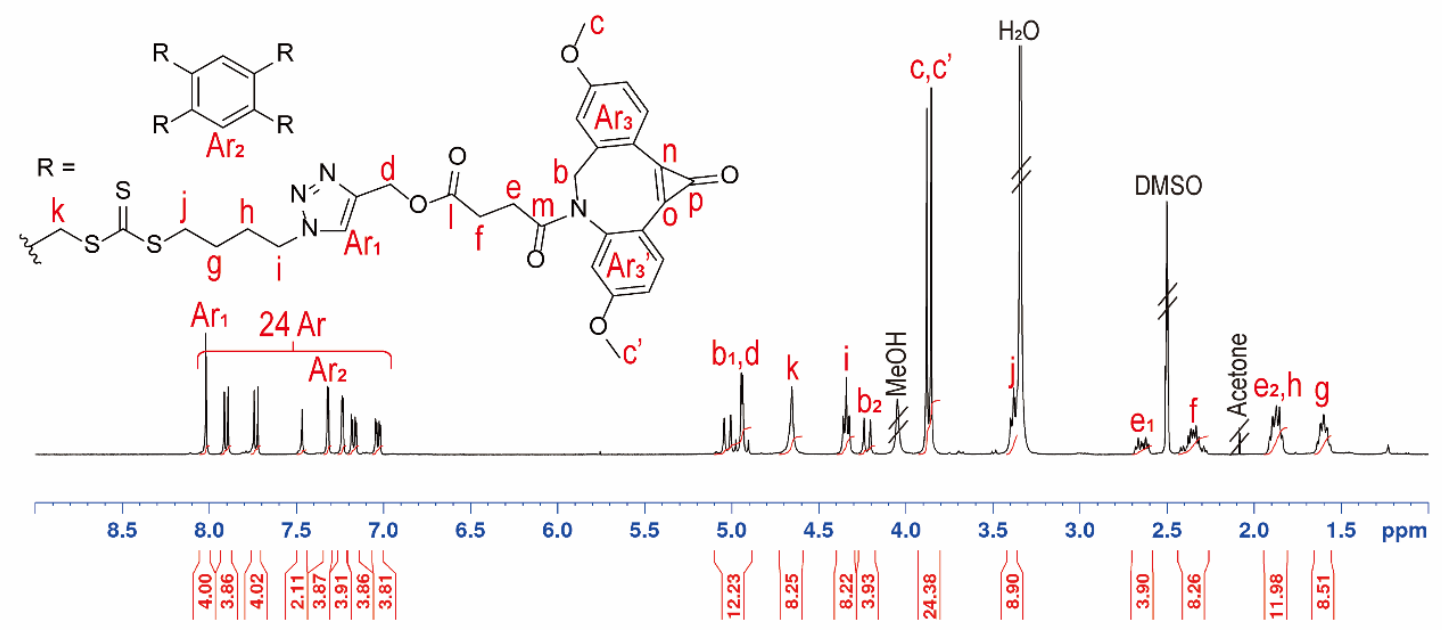

Figure S18. ${ }^{1} \mathrm{H}$ NMR (400 MHz, d6-DMSO) of R4 


\section{Additional figures and tables}

Table S1: ${ }^{1} \mathrm{H}$ NMR and GPC results of cp-DIBAC copolymerized linear polymers before and after clicking

\begin{tabular}{|c|c|c|c|c|c|c|c|c|c|}
\hline \multirow{2}{*}{$\#$} & \multirow{2}{*}{ Monomer } & \multirow{2}{*}{$\begin{array}{l}\mathrm{DP}_{\text {targ }} \\
\text { (total) }\end{array}$} & \multirow{2}{*}{$\begin{array}{c}\%(\mathrm{~mol}) \\
\mathbf{1}\end{array}$} & \multirow{2}{*}{$\begin{array}{c}X \\
(\%)\end{array}$} & \multicolumn{3}{|c|}{ Polymerized } & \multicolumn{2}{|c|}{ Clicked } \\
\hline & & & & & $M_{\mathrm{n}, \text { theo }}$ & $M_{\mathrm{n}, \mathrm{GPC}}$ & Đ & $M_{\mathrm{n}, \mathrm{GPC}}$ & 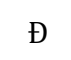 \\
\hline 1 & DMA & 200 & 2.5 & 98 & 21.9 & 27.7 & 1.15 & 37.7 & 1.29 \\
\hline 2 & DMA & 200 & 5 & 95 & 23.5 & 29.1 & 1.15 & 41.7 & 1.30 \\
\hline 3 & DMA & 200 & 7.5 & 91 & 25.3 & 23.6 & 1.11 & 46.1 & 1.26 \\
\hline 4 & DMA & 400 & 5 & 92 & 46.7 & 55.1 & 1.27 & 82.1 & 1.34 \\
\hline 5 & HEA & 200 & 5 & 93 & 26.6 & 40.4 & 1.27 & 51.2 & 1.26 \\
\hline 6 & HEA & 400 & 5 & 89 & 52.9 & 70.6 & 1.44 & 94.3 & 1.35 \\
\hline
\end{tabular}

Table S2. ${ }^{1} \mathrm{H}$ NMR and GPC results of polymerized, deprotected and click on star polymers

\begin{tabular}{|c|c|c|c|c|c|c|c|c|c|c|}
\hline \multirow[t]{2}{*}{$\#$} & \multirow[t]{2}{*}{ CTA } & \multirow{2}{*}{$\begin{array}{l}\text { DPtarg } \\
\text { (total) }\end{array}$} & \multirow{2}{*}{$\begin{array}{c}X \\
(\%)\end{array}$} & \multicolumn{3}{|c|}{ Polymerized } & \multicolumn{2}{|c|}{ Deprotected } & \multicolumn{2}{|c|}{ Clicked } \\
\hline & & & & $M_{\mathrm{n}, \text { theo }}$ & $M_{\mathrm{n}, \mathrm{GPC}}$ & $Đ$ & $M_{\mathrm{n}, \mathrm{GPC}}$ & $Đ$ & $M_{\mathrm{n}, \mathrm{GPC}}$ & $Đ$ \\
\hline 1 & 2 & 200 & 61 & 13.4 & 17.8 & 1.16 & 18.2 & 1.13 & 21.6 & 1.12 \\
\hline 2 & 2 & 400 & 63 & 27.0 & 32.1 & 1.22 & 32.5 & 1.23 & 38.4 & 1.34 \\
\hline 3 & 3 & 200 & 55 & 13.5 & 14.4 & 1.04 & 14.3 & 1.07 & 19.4 & 1.07 \\
\hline 4 & 3 & 400 & 63 & 27.7 & 23.7 & 1.10 & 23.9 & 1.12 & 30.1 & 1.19 \\
\hline 5 & 4 & 200 & 94 & 21.2 & 14.1 & 1.19 & 13.9 & 1.21 & 17.1 & 1.18 \\
\hline 6 & 4 & 400 & 74 & 32.0 & 17.6 & 1.33 & 18.0 & 1.40 & 21.3 & 1.31 \\
\hline
\end{tabular}




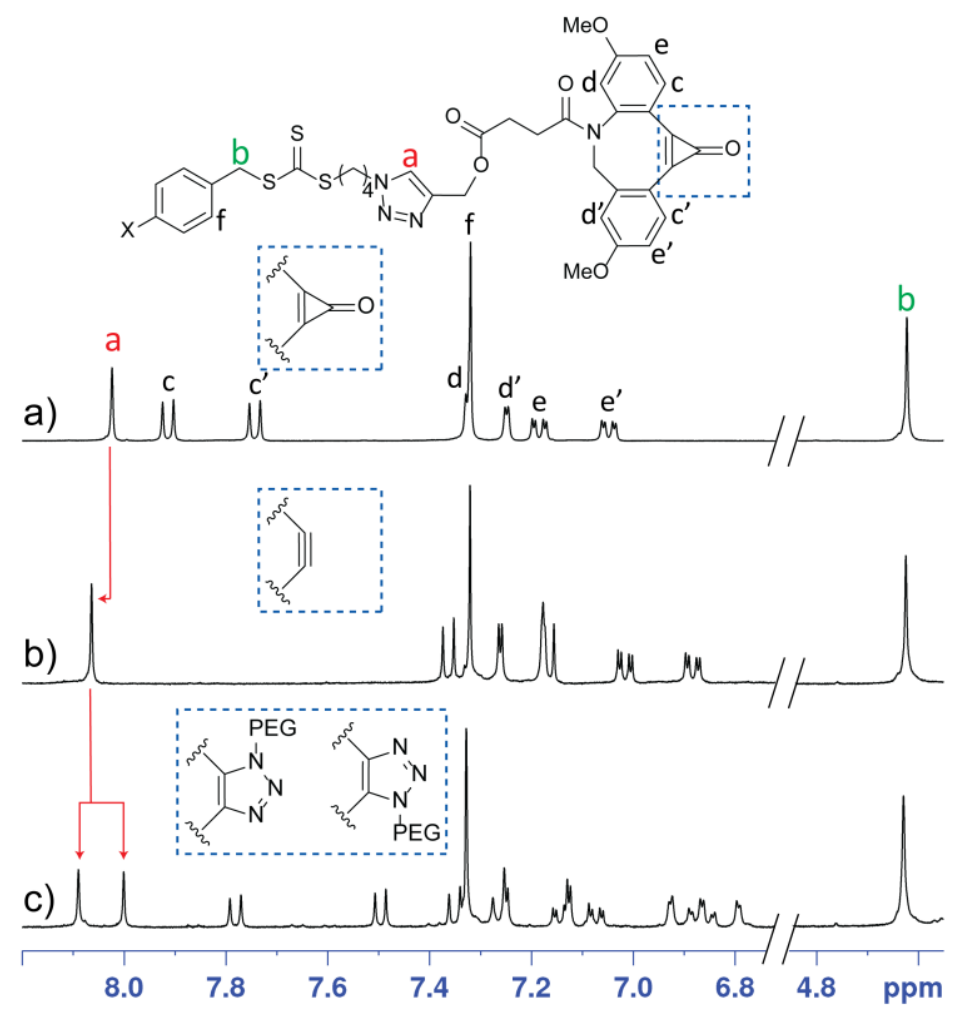

Figure S19. Deprotection and click of 2-arm star RAFT agent (R2) by ${ }^{1} \mathrm{H}$ NMR (d6-DMSO). a) Before and b) after deprotection ( $3 \mathrm{~h} \mathrm{UV}$ ) and c) after addition of 1.0 eq of 400 PEG-N3 with respect to DIBAC.

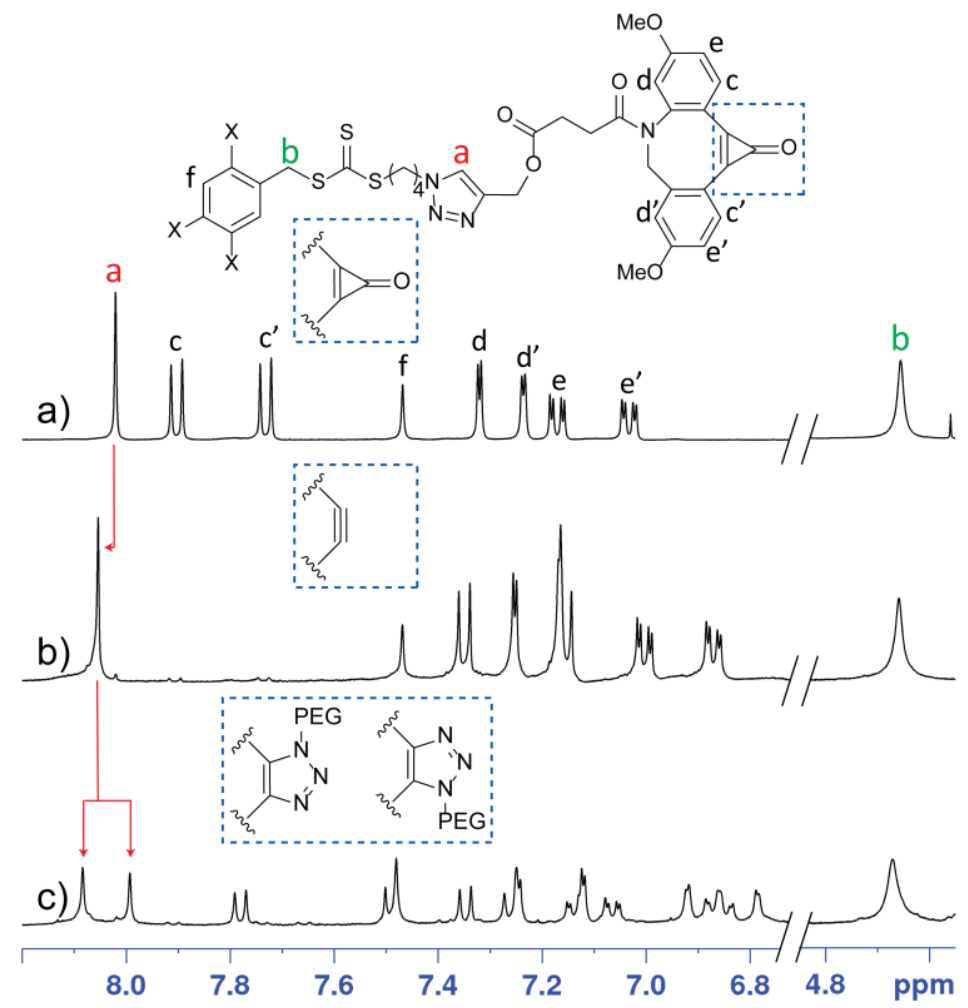

Figure S20. Deprotection and click of 4-arm star RAFT agent (R4) by ${ }^{1} \mathrm{H}$ NMR (d6-DMSO). a) Before and b) after deprotection ( $3 \mathrm{~h} \mathrm{UV}$ ) and c) after addition of 1.0 eq of 400 PEG-N3 with respect to DIBAC. 
Step1: Conjugation via DBCO-NHS

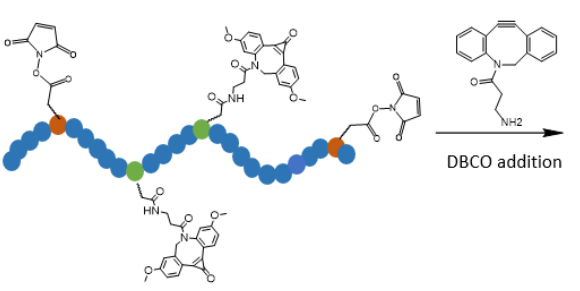

NHS ester and cp-DIBAC incorporated

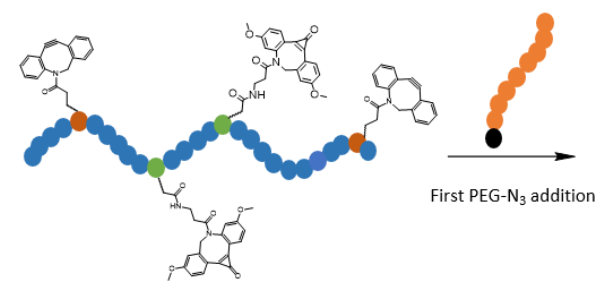

$\mathrm{DBCO}$ and $\mathrm{cp}$-DIBAC functional handles on polymer backbone

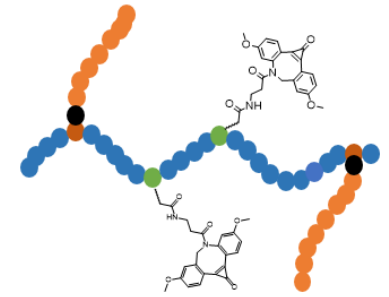

First conjugation

Step2: Conjugation via cp-DIBAC deprotection

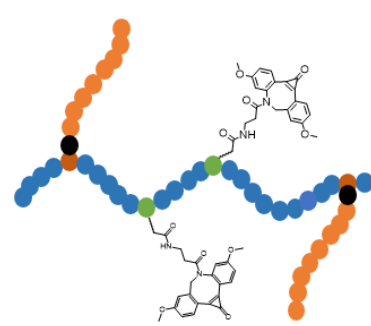

cD-DIBAC functional handle available

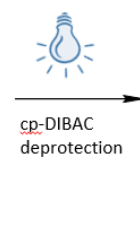

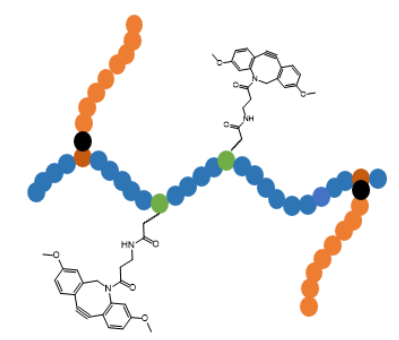

cp-DIBAC deprotected

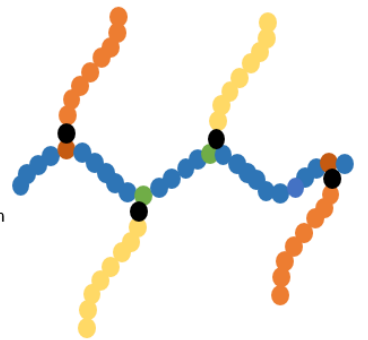

Second conjugation

Figure S21. Schematic showing dual functionalization capabilities using DBCO and cp-DIBAC via SPAAC

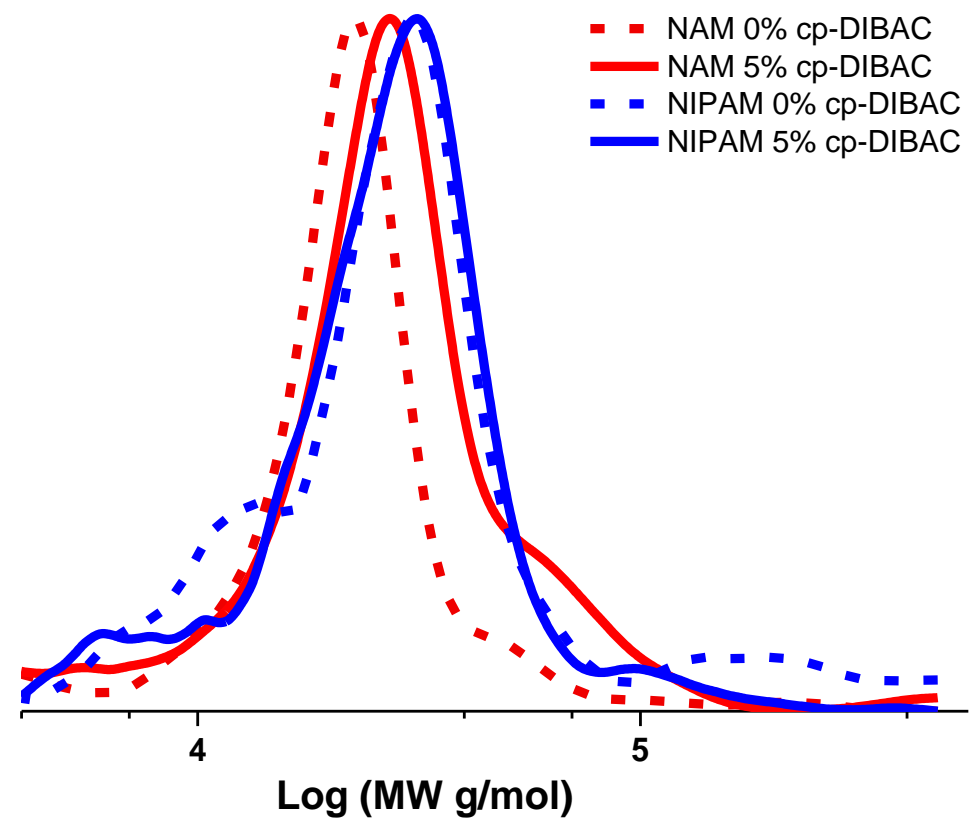

Figure S22. NAM and NIPAM (DP 200) copolymerized with 5\% cp-DIBAC monomer shows its compatibility with various monomers. 
Table S3. GPC characterisation of NAM and NIPAAM linear polymers prepared with $0 \%$ and $5 \% \mathrm{cp}$ DIBAC (M1).

\begin{tabular}{ccccccc} 
Monomer & \% cp-DIBAC & DP & $\boldsymbol{M}_{\mathbf{n}, \text { Theo }}$ & $\boldsymbol{M}_{\mathbf{n}, \mathbf{G P C}}$ & $\boldsymbol{M}_{\mathbf{w}, \mathbf{G P C}}$ & $\boldsymbol{D}$ \\
\hline NAM & 0 & 200 & 28.6 & 19.8 & 22.3 & 1.12 \\
NAM & 5 & 200 & 31.1 & 24.0 & 29.0 & 1.20 \\
NIPAM & 0 & 200 & 23.0 & 26.9 & 30.0 & 1.11 \\
NIPAM & 5 & 200 & 26.0 & 25.1 & 28.4 & 1.12 \\
\hline
\end{tabular}

Table S4. Dual conjugation study molecular weight data for DMA DP 200 2.5\% DBCO 2.5\% cpDIBAC composition

\begin{tabular}{ccccc}
\hline Polymer & $\boldsymbol{M}_{\mathbf{n}, \text { Theo }}$ & $\boldsymbol{M}_{\mathbf{n}, \mathbf{G P C}}$ & $\boldsymbol{M}_{\mathbf{w}, \mathbf{G P C}}$ & $\boldsymbol{\boldsymbol { D }}$ \\
\hline DMA 0\% NHS 0\% cp-DIBAC & 20.2 & 23.1 & 24.9 & 1.08 \\
DMA 2.5\% NHS 2.5\% cp-DIBAC & 22.7 & 23.6 & 26.1 & 1.10 \\
First PEG addition & & 36.0 & 45.5 & 1.26 \\
Second PEG addition & & 43.2 & 53.7 & 1.24 \\
\hline
\end{tabular}

Table S5. DMA DP 200 5\% cp-DIBAC molecular weight data at various time points

\begin{tabular}{cccc} 
DMA 5\% cp-DIBAC (DP 200) & $\boldsymbol{M}_{\mathbf{n}, \mathbf{G P C}}$ & $\boldsymbol{M}_{\mathbf{w}, \mathbf{G P C}}$ & $\boldsymbol{D}$ \\
\hline $\mathrm{t}=8 \mathrm{~h}$ & 14.6 & 15.7 & 1.08 \\
$\mathrm{t}=12 \mathrm{~h}$ & 19.1 & 21.8 & 1.14 \\
$\mathrm{t}=16 \mathrm{~h}$ & 22.9 & 27.2 & 1.18 \\
\hline
\end{tabular}



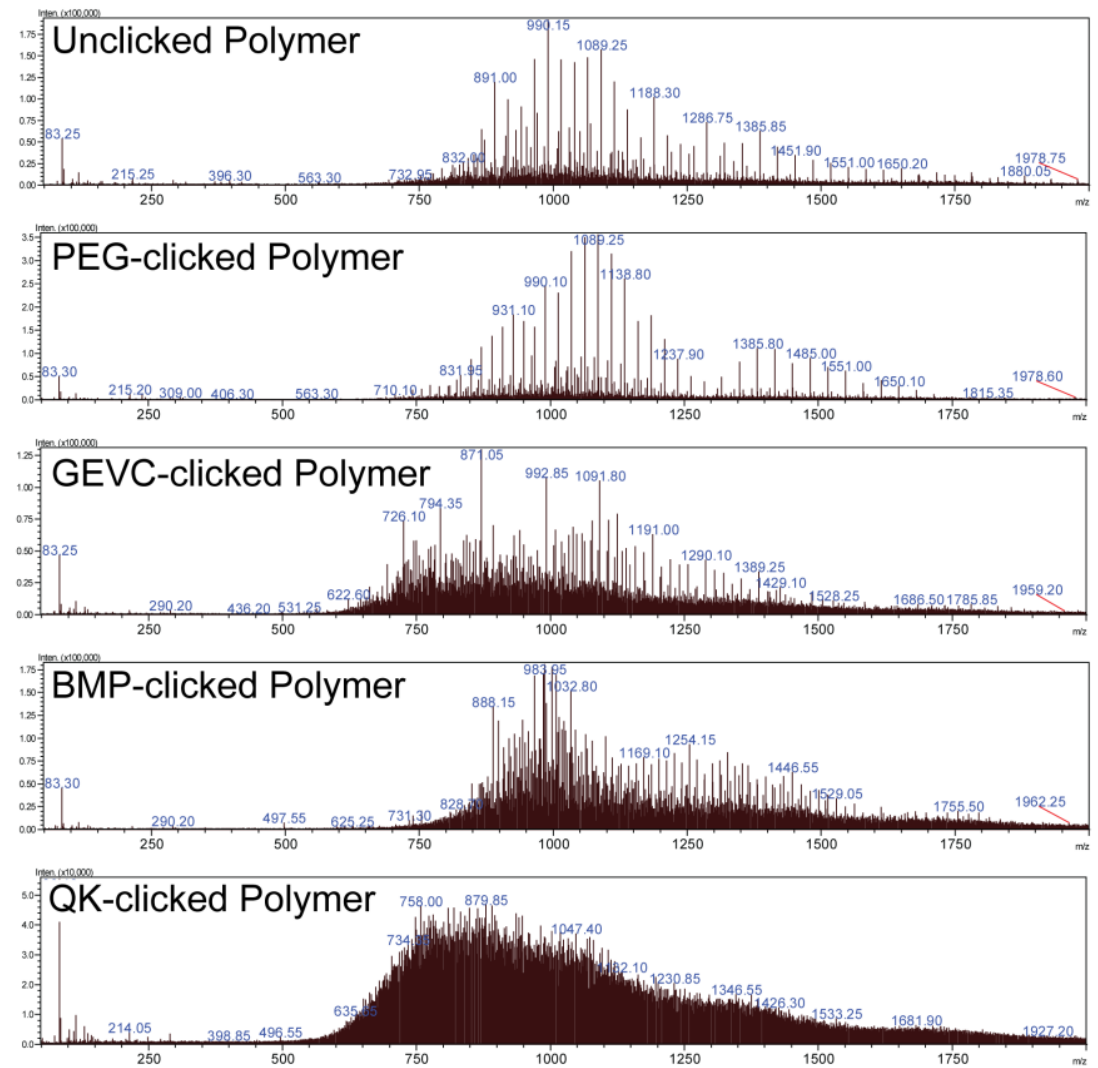

Figure S23. ESI-MS spectra for the 2-arm $\mathrm{DMA}_{20}$ polymer peaks shown in Figure 7a before click (0) and after click $(\bullet)$ to PEG-N $\mathrm{N}_{3}(400 \mathrm{Da}), \mathrm{GEVC}, \mathrm{BMP}$ and QK peptides confirming the identity of these peaks.
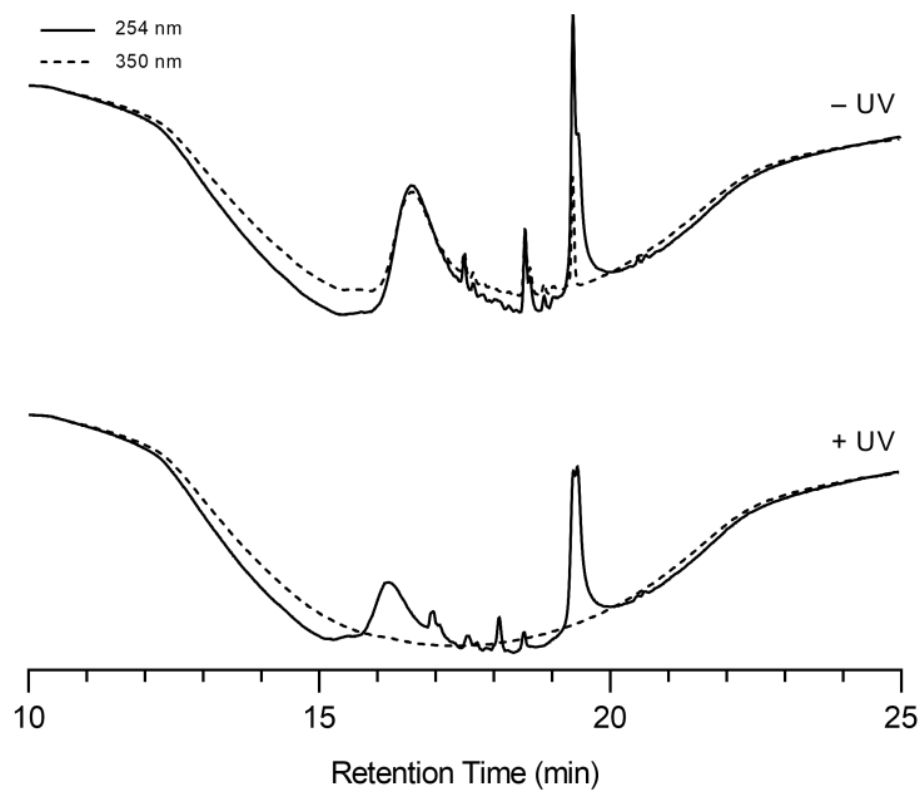

Figure S24. Photodiode array (PDA) detector chromatogram data for the PEG- $\mathrm{N}_{3}$ (400 Da) traces in Figure $7 \mathrm{a}$ at 254 and $350 \mathrm{~nm}$. The loss of signal at $350 \mathrm{~nm}$ in the polymer peak can be seen after UV irradiation, consistent with full deprotection of the polymer. 


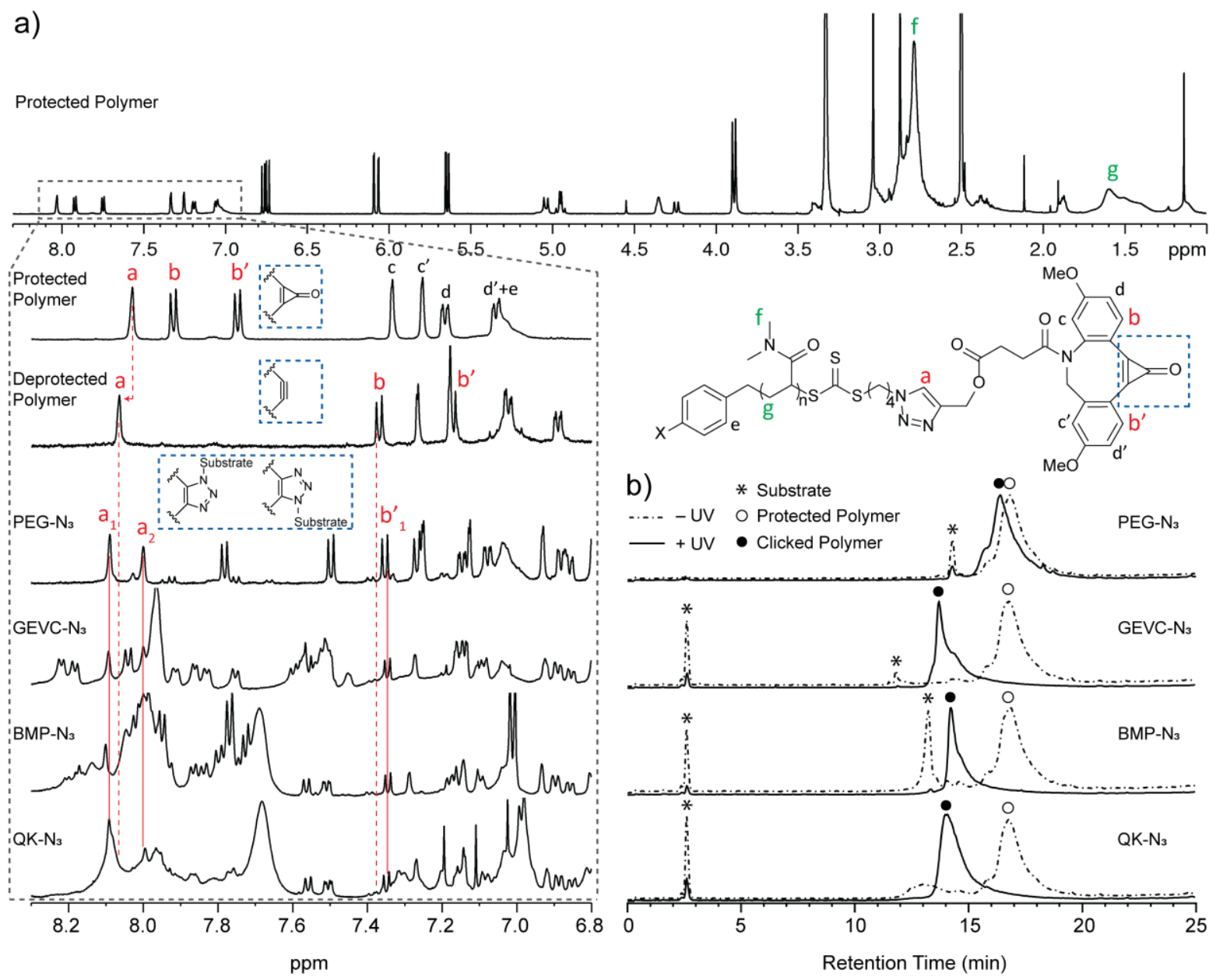

Figure S25. a) ${ }^{1} \mathrm{H}-\mathrm{NMR}$ (d6-DMSO) for the 2-arm DP20 pDMA shown in Figure 7a (reproduced here as figure b) before and after deprotection, and after click to PEG-N $\mathrm{N}_{3}(400 \mathrm{Da}), \mathrm{GEVC}, \mathrm{BMP}$ and QK peptides. 


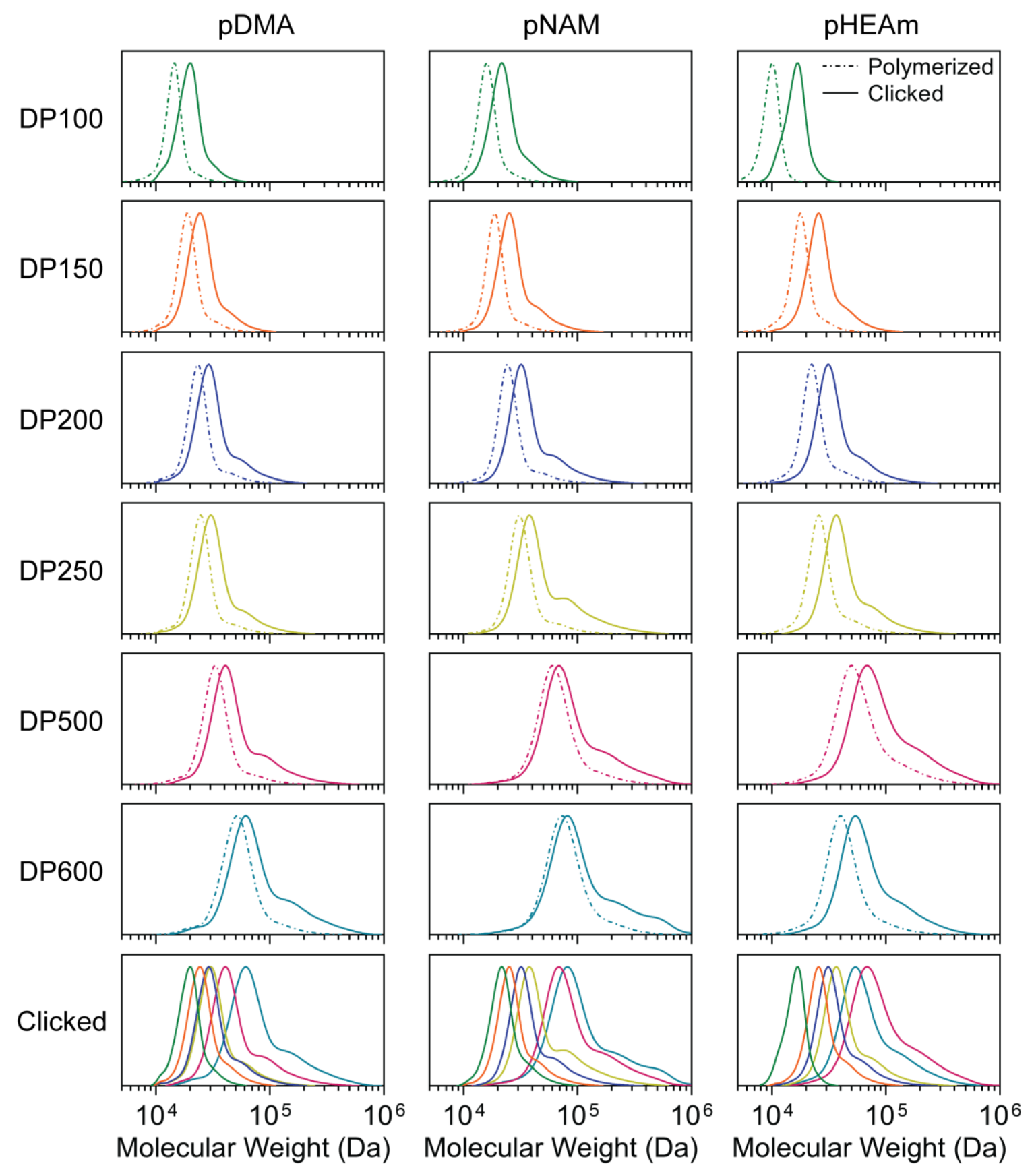

Figure S26. Library of 3-arm polymers. GPC traces of 3-arm star polymer libraries of dimethyl acrylamide (DMA), $\mathrm{N}$-acryloyl morpholine (NAM) and 2-hydroxyethyl acrylamide (HEAm) shown in Figure $7 \mathrm{~b}$ before and after click with PEG-N $\mathrm{N}_{3}(2 \mathrm{kDa})$. 


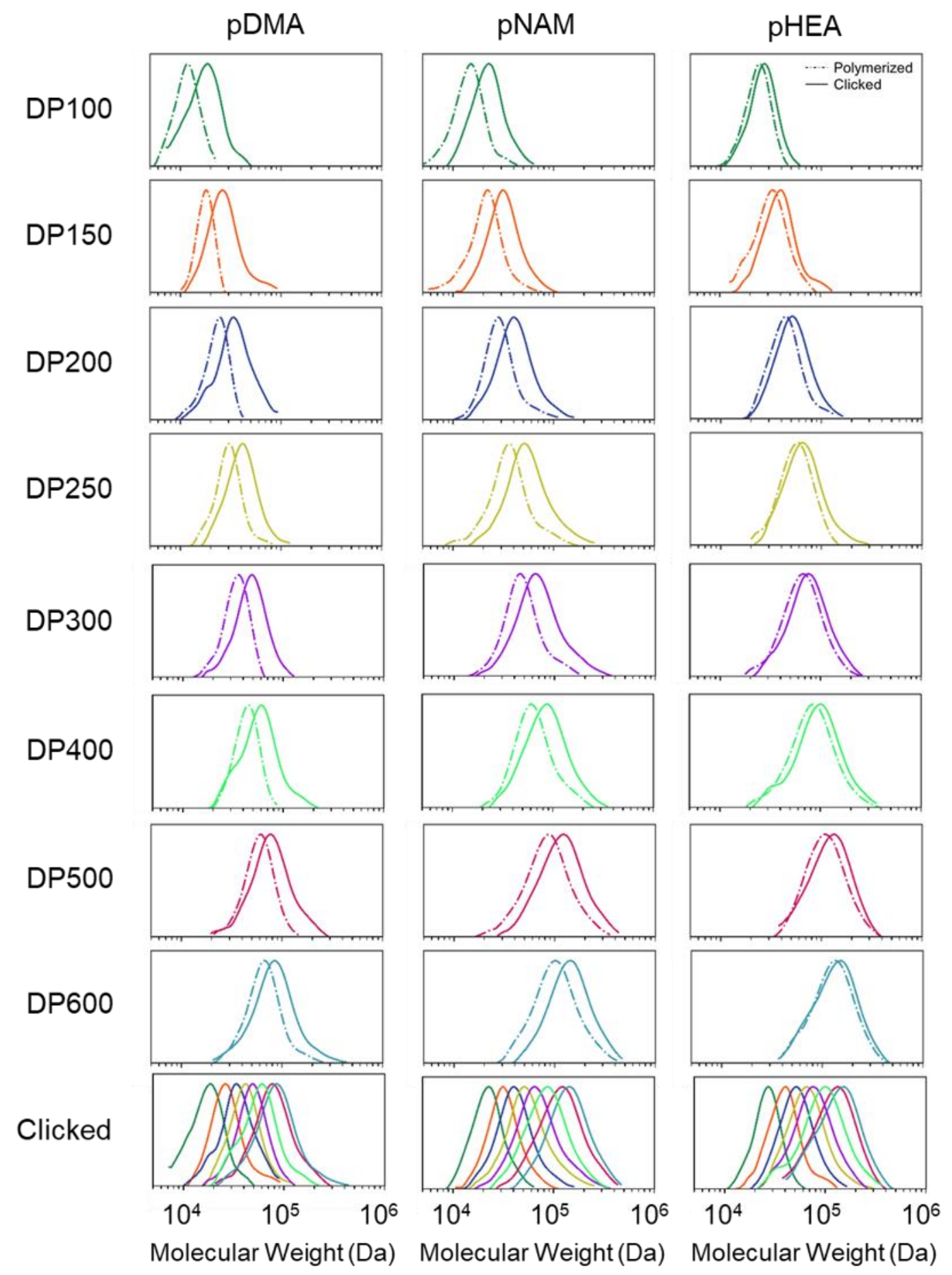

Figure S27. Library of linear polymers. GPC traces of linear polymer libraries of dimethyl acrylamide (DMA), $\mathrm{N}$-acryloyl morpholine (NAM) and 2-hydroxyethyl acrylamide (HEAm) shown in Figure 7b before and after click with PEG-N $3(2 \mathrm{kDa})$. 
Table S6. GPC molecular weight (in $\mathrm{kDa}$ ) and dispersity information for linear and 3-arm library shown in Figure 7

\begin{tabular}{|c|c|c|c|c|c|c|c|c|c|c|c|c|}
\hline \multirow{3}{*}{$\begin{array}{c}\text { Target } \\
\text { DP (total) }\end{array}$} & \multicolumn{4}{|c|}{ DMA } & \multicolumn{4}{|c|}{ NAM } & \multicolumn{4}{|c|}{ HEAm } \\
\hline & \multicolumn{2}{|c|}{ Before click } & \multicolumn{2}{|c|}{+ PEG-N3 } & \multicolumn{2}{|c|}{ Before click } & \multicolumn{2}{|c|}{+ PEG-N 3} & \multicolumn{2}{|c|}{ Before click } & \multicolumn{2}{|c|}{+ PEG-N 3} \\
\hline & $M_{\mathbf{n}}$ & Ð & $M_{\mathbf{n}}$ & Đ & $M_{\mathbf{n}}$ & Ð & $M \mathbf{n}$ & $\mathbf{D}$ & $M_{\mathbf{n}}$ & $\mathbf{D}$ & $M_{\mathbf{n}}$ & Đ \\
\hline \multicolumn{13}{|c|}{ Linear (5\% cpDIBAC) } \\
\hline 100 & 11.3 & 1.08 & 16.0 & 1.15 & 13.5 & 1.13 & 20.1 & 1.14 & 21.6 & 1.08 & 25.0 & 1.10 \\
\hline 150 & 17.2 & 1.04 & 24.5 & 1.12 & 18.6 & 1.18 & 28.3 & 1.15 & 27.9 & 1.15 & 34.2 & 1.16 \\
\hline 200 & 20.7 & 1.11 & 28.8 & 1.19 & 26.5 & 1.14 & 35.0 & 1.20 & 39.1 & 1.13 & 45.2 & 1.16 \\
\hline 250 & 27.4 & 1.11 & 36.4 & 1.13 & 29.1 & 1.27 & 44.5 & 1.27 & 48.1 & 1.16 & 56.1 & 1.22 \\
\hline 300 & 30.9 & 1.10 & 40.9 & 1.16 & 41.1 & 1.19 & 54.5 & 1.33 & 53.2 & 1.26 & 61.5 & 1.25 \\
\hline 400 & 40.1 & 1.08 & 48.2 & 1.21 & 54.4 & 1.21 & 68.6 & 1.28 & 64.5 & 1.32 & 70.4 & 1.37 \\
\hline 500 & 51.1 & 1.15 & 63.5 & 1.25 & 62.8 & 1.35 & 90.9 & 1.33 & 92.7 & 1.23 & 99.7 & 1.27 \\
\hline 600 & 56.1 & 1.20 & 67.2 & 1.30 & 81.6 & 1.31 & 114.3 & 1.27 & 103.9 & 1.26 & 109.0 & 1.29 \\
\hline \multicolumn{13}{|l|}{ 3-arm star } \\
\hline 100 & 13.8 & 1.05 & 18.4 & 1.07 & 15.2 & 1.06 & 20.6 & 1.10 & 9.6 & 1.03 & 15.3 & 1.05 \\
\hline 150 & 17.8 & 1.07 & 22.9 & 1.11 & 18.0 & 1.06 & 24.7 & 1.14 & 16.8 & 1.07 & 24.6 & 1.12 \\
\hline 200 & 21.9 & 1.10 & 27.7 & 1.17 & 23.5 & 1.10 & 32.5 & 1.20 & 21.2 & 1.10 & 30.4 & 1.18 \\
\hline 250 & 23.0 & 1.14 & 28.8 & 1.18 & 29.6 & 1.12 & 39.9 & 1.35 & 24.5 & 1.13 & 36.5 & 1.22 \\
\hline 500 & 30.0 & 1.15 & 39.9 & 1.30 & 54.4 & 1.23 & 67.0 & 1.46 & 46.2 & 1.33 & 67.0 & 1.48 \\
\hline 600 & 44.1 & 1.22 & 57.7 & 1.47 & 63.1 & 1.29 & 75.8 & 1.63 & 35.1 & 1.23 & 52.4 & 1.39 \\
\hline
\end{tabular}

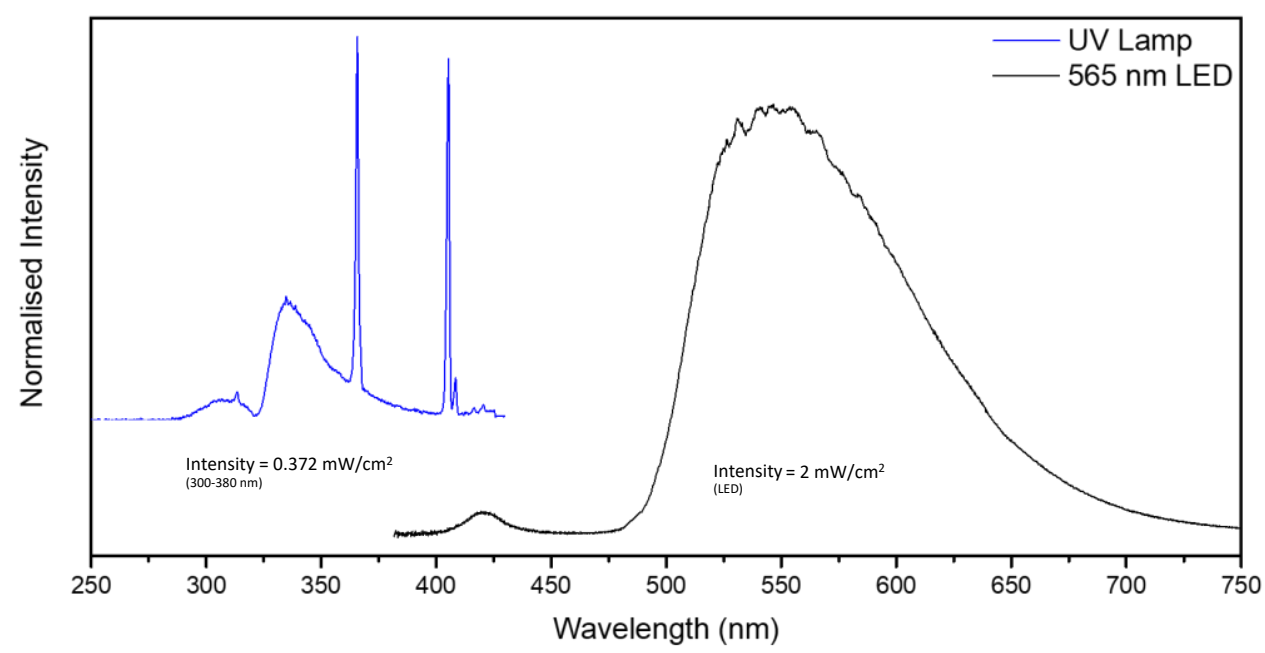

Figure S28. Emission spectra of the Cosmedico ARIMED B6 UV lamp (blue) and the Thorlabs M565L3 LED (black) used for the polymerisation and deprotection of the star polymer systems. The UV power was measured using a 355/40 Thorlabs filter over the power head (blue spectrum) to remove some of the background light. This bandpass allows transmission of 300-380 nm light. Spectra of the lamps used for the linear systems are assumed to be similar but were not measured. Power values for all spectra are included in the manuscript. 


\section{References}

(1) Kramer, J. J. P.; Nieger, M.; Bräse, S. Synthesis of Planar Chiral N-Heterocyclic-Substituted Pyridinophanes. Eur. J. Org. Chem. 2013, 2013 (3), 541-549. DOI:

https://doi.org/10.1002/ejoc.201201286 